\title{
Apolipoprotein B and Cardiovascular Disease: Biomarker and Potential Therapeutic Target
}

\author{
Jennifer Behbodikhah, Saba Ahmed D, Ailin Elyasi, Lora J. Kasselman, Joshua De Leon, Amy D. Glass \\ and Allison B. Reiss * (D)
}

Citation: Behbodikhah, J.; Ahmed, S.; Elyasi, A.; Kasselman, L.J.; De Leon,

J.; Glass, A.D.; Reiss, A.B.

Apolipoprotein B and Cardiovascular Disease: Biomarker and Potential Therapeutic Target. Metabolites 2021, 11, 690. https://doi.org/10.3390/ metabo11100690

Academic Editor: Manfredi Rizzo

Received: 23 August 2021

Accepted: 6 October 2021

Published: 8 October 2021

Publisher's Note: MDPI stays neutral with regard to jurisdictional claims in published maps and institutional affiliations.

Copyright: (c) 2021 by the authors. Licensee MDPI, Basel, Switzerland. This article is an open access article distributed under the terms and conditions of the Creative Commons Attribution (CC BY) license (https:/ / creativecommons.org/licenses/by/ $4.0 /)$.
Department of Medicine and Biomedical Research Institute, NYU Long Island School of Medicine, NYU Langone Hospital_Long Island, Mineola, NY 11501, USA; Jennifer.Behbodikhah@nyulangone.org (J.B.); Saba.Ahmed@NYULangone.org (S.A.); ailinelyasi1@gmail.com (A.E.); Lora.Kasselman@NYULangone.org (L.J.K.); Joshua.DeLeon@NYULangone.org (J.D.L.); ADG237@optonline.net (A.D.G.)

* Correspondence: Allison.Reiss@NYULangone.org; Tel.: +1-516-663-3455

\begin{abstract}
Apolipoprotein (apo) B, the critical structural protein of the atherogenic lipoproteins, has two major isoforms: apoB48 and apoB100. ApoB48 is found in chylomicrons and chylomicron remnants with one apoB48 molecule per chylomicron particle. Similarly, a single apoB100 molecule is contained per particle of very-low-density lipoprotein (VLDL), intermediate density lipoprotein, LDL and lipoprotein(a). This unique one apoB per particle ratio makes plasma apoB concentration a direct measure of the number of circulating atherogenic lipoproteins. ApoB levels indicate the atherogenic particle concentration independent of the particle cholesterol content, which is variable. While LDL, the major cholesterol-carrying serum lipoprotein, is the primary therapeutic target for management and prevention of atherosclerotic cardiovascular disease, there is strong evidence that apoB is a more accurate indicator of cardiovascular risk than either total cholesterol or LDL cholesterol. This review examines multiple aspects of apoB structure and function, with a focus on the controversy over use of apoB as a therapeutic target in clinical practice. Ongoing coronary artery disease residual risk, despite lipid-lowering treatment, has left patients and clinicians with unsatisfactory options for monitoring cardiovascular health. At the present time, the substitution of apoB for LDL-C in cardiovascular disease prevention guidelines has been deemed unjustified, but discussions continue.
\end{abstract}

Keywords: apolipoprotein B; LDL-C; atherosclerosis; biomarker; statin

\section{Introduction}

Cardiovascular disease (CVD) is the leading cause of death worldwide and its prevalence is expected to continue to rise over the next 15 years [1,2]. According to the American Heart Association (AHA), one in three people will be affected by some form of CVD during their lifetime [3]. The two most common clinical manifestations of CVD are coronary artery disease (CAD) and ischemic stroke [4]. As a major cause of morbidity and mortality in the United States of America and worldwide, complications of atherosclerosis, including myocardial infarction, chronic kidney disease and stroke, are major contributors to the financial burden of healthcare costs [5,6]. The overall approach to reducing CVD morbidity and mortality is focused on primary and secondary prevention and control of modifiable risk factors $[7,8]$. Despite all efforts, substantial residual risk remains and new lines of attack against atherosclerotic CVD are needed [9]. One avenue that merits exploration is apolipoprotein B (apoB) and its prominent position as a causal factor in atherosclerosis [10].

Atherosclerosis is a progressive disease of large- and medium-sized muscular arteries, characterized by elevated lesions called fibrous plaques that encroach upon the vessel lumen and disturb blood flow. Atherosclerosis is the major cause of CVD. A hallmark of atherosclerosis is the retention of cholesterol-rich low-density lipoprotein (LDL) and other apoB-containing lipoproteins within the arterial wall (Figure 1) [11]. Development of the 
fatty streak and subsequent transition to fibrous plaque is primarily dependent upon the absorption of modified forms of cholesterol by subendothelial macrophages in an inflammatory setting. Thus, elevated levels of cholesterol in the circulation promote atherosclerosis and CVD $[12,13]$. Measurement of serum apoB reflects total LDL-C, intermediate density lipoproteins (IDL-C), VLDL-C, and lipoprotein(a) (Lp(a)) particle concentrations because each particle contains exactly one molecule of apoB100. Thus, apoB can be considered a powerful tool for assessment of atherogenic lipid status.

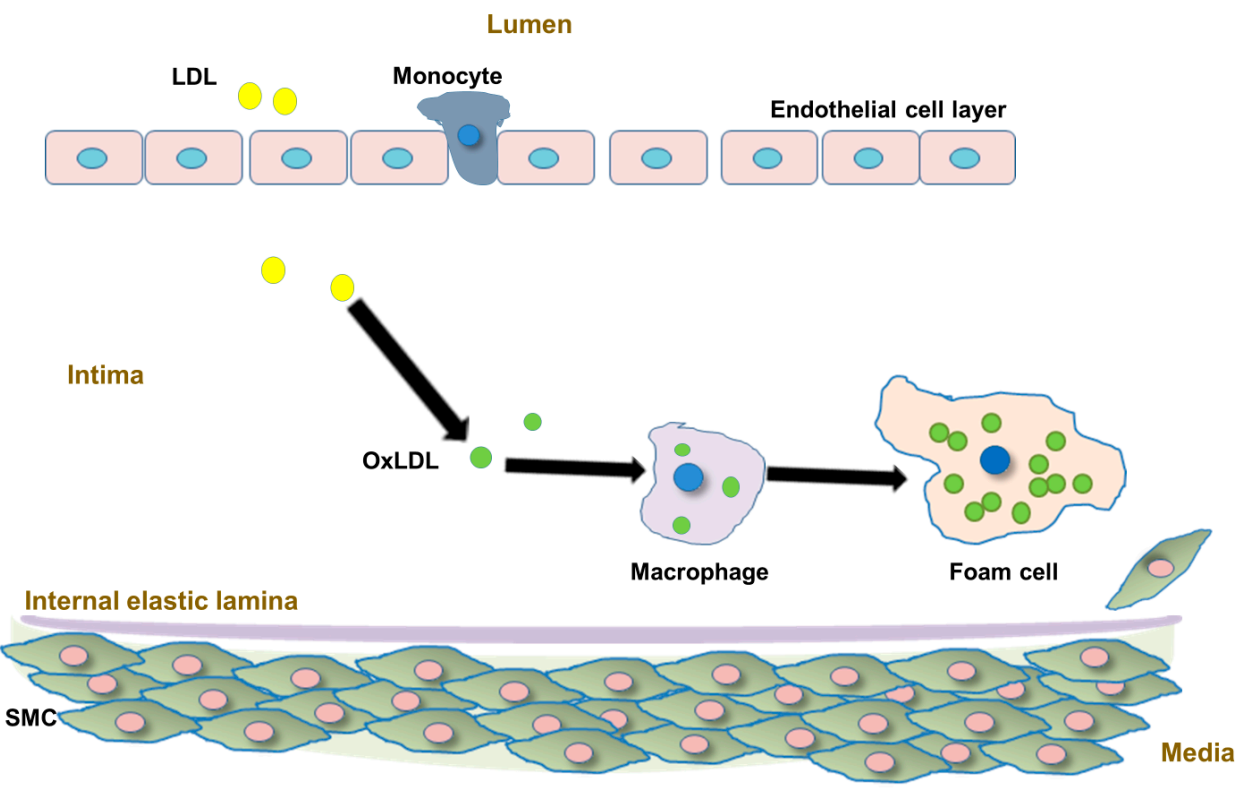

Figure 1. Atherosclerosis involves apoB-containing lipoproteins. The atherosclerotic process begins with compromise of the endothelial barrier, allowing apoB-containing LDL cholesterol to migrate into the arterial intima. Activated endothelium fosters attachment, migration and proliferation of vascular smooth muscle cells (SMC) and macrophages. Retained apoB-containing lipoproteins are oxidatively modified within the vascular intima. Oxidized (ox)LDL contains protein components, creating a net negative charge, making the particles highly attractive to macrophages. Phagocytosis allows for the accumulation of lipids within macrophages, producing foam cells. OxLDL-laden foam cells amass and form the fatty streak and eventually the lumen-narrowing atheromatous plaque that restricts blood flow. Additionally, inflammatory signaling pathways are activated, leading to increased cell migration and LDL modification.

ApoB is a key structural protein component of all major atherogenic lipoproteins. It plays multiple roles in regulating lipid metabolism and is considered to be a physiologically relevant measure of actual number of atherogenic lipid particles. This review will explore the importance of apoB in the atherosclerotic process and its potential role as a biomarker and treatment target. The structure and function of apoB will be discussed. Areas of conflict and controversy will be addressed. In addition, we will focus on future directions of lipidlowering agents and whether or not apoB should play a more central role in controlling and monitoring dyslipidemia.

\section{ApoB: Characteristics and Composition}

The protein constituents of lipoproteins, apolipoproteins, are found bound to the lipoprotein surface and are largely responsible for the lipoprotein properties, transport and metabolism [13-15]. Of the numerous apolipoproteins, apoB is an essential component of VLDLs and its metabolites IDLs and LDLs as well as chylomicrons and their remnants [14]. The apoB particle serves as a frame and is crucial in the maintenance of the structural stability of the lipoprotein (Figure 2) [16,17]. 


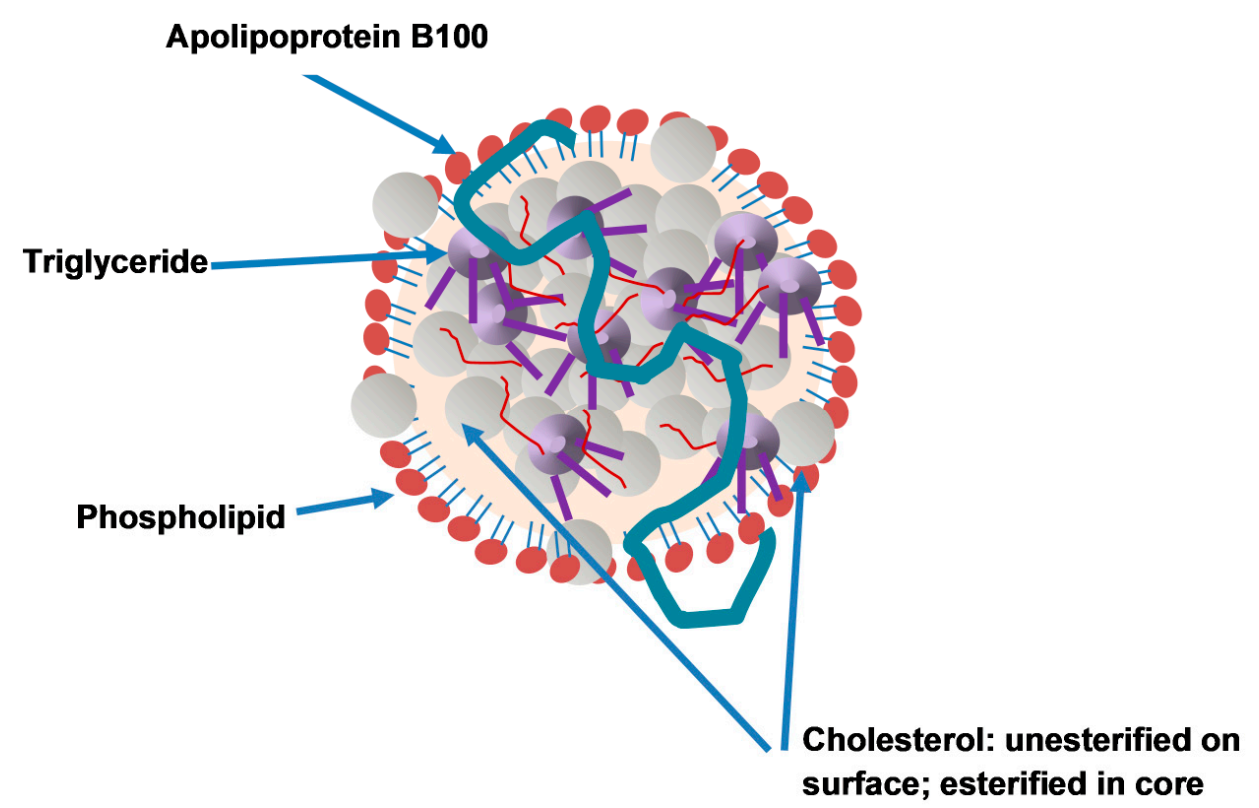

Figure 2. Apo B in a lipoprotein particle. A single molecule of apoB is irreversibly bound to the surface of the lipoprotein particle. The lipid content of the surface consists of a monolayer of phospholipid and free cholesterol. The hydrophobic core is composed of triglyceride and cholesterol esters.

ApoB is encoded by the APOB gene, and occurs in two forms: full-length apoB100, consisting of 4536 amino acids; and apoB48, a truncated form consisting of the N-terminal 2152 amino acids [18-21]. Although encoded by the same gene, they play distinct roles in physiology. In humans, apoB48 is primarily synthesized and expressed within the intestine and is present in chylomicrons and their remnants [22,23]. In contrast, apoB100 is mainly synthesized and expressed in the liver and is an integral component of VLDL, IDL and LDL (Figure 3) $[24,25]$. Therefore, of the two forms, apoB100 is more clinically relevant in determining the level of circulating atherogenic lipoproteins [26]. Amongst the plasma apolipoproteins, apoB100 is unique not only because of its large size but also due to its moderate hydrophobicity and inability to transfer between lipoproteins [27-30].

The apoB100 polypeptide is made up of five domains: $\beta \alpha 1, \beta 1, \alpha 2, \beta 2$, and $\alpha 3$, with $\alpha$ representing a predominantly $\alpha$-helical structure and $\beta$ representing a predominantly $\beta$-sheet structure [31-33]. The $\mathrm{N}$-terminal sequence is vital in the formation of VLDL due to its interaction with the microsomal triglyceride transfer protein (MTP) [34,35]. MTP in the endoplasmic reticulum is required for the first step in apoB generation, transfer of triglycerides, phospholipids and cholesterol esters to the apoB particle [36]. The $\beta$-sheet domains are fundamental in establishing irreversible strong bonds to the lipid core that keep lipoproteins anchored to the original apoB particle to which they have been attached [14]. An amphipathic $\alpha$-helix domain is located between the two $\beta$-sheet domains, typical in other apolipoprotein structures as well [37]. Elongation of the $\beta$-sheet domains around the lipoprotein imbues apoB100 with a distinct amphipathic quality which allows the stable binding of lipids, especially those within the lipoprotein core [16,32]. These lipidassociating regions are key features for the integrity of LDL particles. 


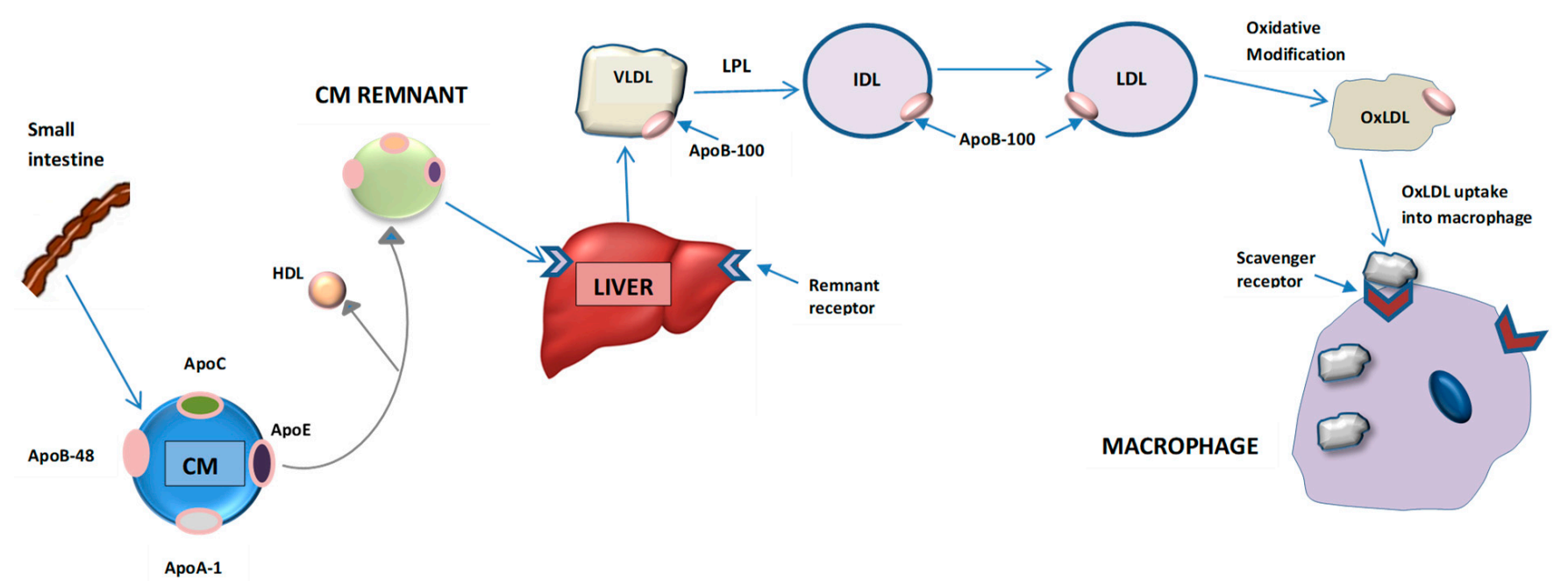

Figure 3. Apolipoprotein (apo) B in atherogenic lipoprotein formation. ApoB is the critical structural protein of all atherogenic lipoproteins. It has two major isoforms: apoB48 and apoB100. ApoB48 is found only in chylomicrons (CM) and chylomicron remnants. It mediates the secretion of chylomicron particles from the intestines. Chylomicron remnants are taken up by the liver. Free fatty acids generated from chylomicron remnants are used by the liver to make triglycerides that are incorporated into nascent VLDL. VLDL particles, each harboring a single apoB100 molecule, are secreted from the liver carrying endogenous, hepatically synthesized triglycerides. VLDL particles shrink with loss of surface components to HDL and are catabolized to IDL by lipoprotein lipase (LPL). Then, IDL is converted to LDL. It is LDL that carries the majority of the circulating cholesterol. LDL can be oxidatively modified and taken up by macrophages which leads to excess accumulation and the formation of foam cells.

Ribosomes on the surface of the endoplasmic reticulum synthesize apoB100, which is subsequently translocated through a channel to the lumen of the endoplasmic reticulum. ApoB100 secretion is regulated primarily at the post-translational stage $[13,38,39]$. Typically, secretory proteins are synthesized on the cytosolic surface of the ER followed by rapid translocation through the membrane to the lumen of the ER. However, apoB100 is unlike other secretory proteins in that it becomes associated with the ER membrane very early in the post-translational period, resulting in exposure of the nascent polypeptide to the cytosol [13]. This exposure allows for between 50 and $80 \%$ degradation of the newly synthesized apoB100 by hepatocytes. Thus, this rapid co-translational degradation predominantly determines the amount of protein secreted by the cells. Furthermore, whether nascent apoB100 is degraded or secreted depends on the availability of the major lipoprotein lipids, triglycerides, cholesteryl esters, and phospholipids [40]. If the amount of lipid available to lipidate apoB in the endoplasmic reticulum is inadequate or if MTP is not functioning properly, the chaperone protein binding immunoglobulin protein (BiP) will bind to apoB and target it for proteasomal degradation [41-43]. Proteasome-independent posttranslational degradation of apoB has also been documented [44]. MTP and the amount of lipids available are major determinants of apoB100 translocation in addition to its assembly and secretion $[14,45,46]$. MTP and apoB100 interact physically at the site of apoB100 translocation across the ER where MTP facilitates the coordinated transfer of lipids and folding of the polypeptide as it exits the ribosome and enters the ER lumen [13,32]. MTP inhibition can block the secretion of apoB100 [13,47]. Subsequent maturation of apoB100 occurs in the golgi apparatus prior to secretion from the hepatocyte [48,49]. The addition of a major load of triglycerides occurs in the golgi apparatus and plays a significant role in determining the size of the VLDL secreted [14,50,51]. Therefore, the amount of triglyceride available in the hepatocytes directly impacts VLDL assembly. States of excess triglyceride production, such as obesity, untreated diabetes mellitus, or in persons consuming a diet high in simple carbohydrates, lead to the formation of triglyceride-rich VLDL [52-54]. After a high-fat meal, the concentration of triglyceride-rich large VLDL and chylomicrons increases [55]. The size and density of apoB-containing particles is directly dependent on the availability 
of triglyceride [56]. A number of additional factors, such as the availability of insulin and fatty acids, can also influence the secretion of these apoB-containing lipoproteins.

In humans, the liver is predominantly responsible for the uptake and disposal of the majority of circulating apoB-containing lipoproteins. Uptake is carried out via three primary receptors: the LDL receptor, heparin sulfate proteoglycans, and scavenger receptor class B type I (SR-BI). The LDL receptor has a half-life of about $25 \mathrm{~h}$ and is responsible for the clearance of more than two-thirds of normal LDL, accomplished via binding to a specific site within the $\alpha 3$ domain of apoB100 $[16,37,57,58]$. The primary binding region that interacts with the LDL receptor, termed site $B$, is located at residues 3356-3368 of apoB [16,57]. Binding between the LDL receptor and apoB100 only occurs after the polypeptide has undergone a conformational change which results due to the lipolysis of VLDL to LDL [59,60]. Loss-of-function mutations in the LDL receptor or apoB can result in familial hypercholesterolemia, which is characterized by extremely elevated plasma LDL levels, thus leading to accelerated atherosclerosis [61]. Additionally, gain-of-function mutations in PCSK9, a proprotein convertase that accelerates the degradation of the LDL receptor, also results in high LDL concentrations [62]. Following endocytosis, LDL separates from the LDL receptor. The LDL, with a long half-life of 2- to 3-days, is transported to the lysosomes where it is degraded and its lipid cargo released, while the majority of LDL receptors are recycled to the cell surface [63-65]. In this way, apoB100 is essential in the catabolism of VLDL, LDL and IDL via its interaction with LDL receptors in the plasma.

In addition to LDL receptor binding sites, apoB100 possesses at least eight potential proteoglycan (PG)-binding sites $[66,67]$. Of these, two sites have been proposed to act cooperatively in the association with proteoglycans: site A at residues 3148-3158 and site B at residues $3359-3369[68,69]$. The main sites that interact with proteoglycans are sites A and $\mathrm{B}$, sites that also bind to the LDL receptor $[14,70]$. ApoB-containing lipoproteins bind to PGs via ionic interactions between the negative charged sulfate and carboxyl groups of the glycosaminoglycans (GAGs) and the positively charged basic amino acid lysine and arginine residues of the apoB100 [16,71]. This binding of apoB100 to proteoglycans in the arterial wall is particularly significant as it is considered to be the primary mechanism for the retention of LDL in the subendothelium [72]. The retention and aggregation of apoBlipoproteins within the arterial wall can be attributed to the intrinsic tendency of damaged or modified apoB100 to aggregate. Proteolysis of apoB by enzymes in the arterial intima can change particle conformation at a molecular level, promoting fusion, aggregation and accumulation in the arterial wall [71,73].

On the other hand, apoB48 is primarily found on chylomicrons and their remnants and is primarily cleared by the heparin sulfate proteoglycan (HSPG) pathway since they do not contain an LDL-receptor binding domain $[74,75]$. The significance is largely found in diabetes, where high glucose interferes with perlecan biosynthesis, resulting in a decrease in HSPG. This leads to elevated plasma levels of apoB48 containing lipoproteins and ultimately severe postprandial dyslipidemia [76]. While chylomicrons themselves are too large to penetrate the arterial wall, their remnants may do so and are therefore thought to contribute to lipid accumulation in atherosclerotic plaque [77].

\section{Biomarkers for CVD: LDL-C and ApoB}

\subsection{The Lipid Profile and LDL-C as a Biomarker}

Currently, the American Heart Association recommends a screening lipid panel every 4-6 years in patients over the age of 20. However, patients with CVD or at high risk of cardiovascular-related events should be screened more frequently [78,79]. A routine lipid panel consists of total cholesterol, HDL-C, LDL-C and triglycerides, along with cholesterol ratios. Total cholesterol, HDL-C and triglycerides are directly measured, whereas the LDL-C levels are estimated using the Friedewald equation. The Friedewald equation, which is subject to inaccuracy in the presence of high triglycerides and other conditions like diabetes, estimates LDL-C as total cholesterol minus HDL-C and very-low-density cholesterol (VLDL-C), with VLDL-C estimated as triglycerides divided by a fixed factor of 
5 [80-83]. Ultracentrifugation followed by $\beta$-quantification is the gold standard to directly measure LDL-C, but this method is impractical, expensive and generally reserved for research use $[84,85]$.

Traditionally, LDL cholesterol has been used to assess the risk associated with CVD and is a frequently used surrogate CVD risk marker in clinical trials [86-89]. However, LDL-C is an imperfect predictor and many individuals with normal LDL-C levels develop CVD [90].

LDL is generally characterized as a combination of cholesterol contained in a variety of lipoproteins defined by a density between 1.006 and $1.063 \mathrm{~g} / \mathrm{mL}$. However, this includes IDL and VLDL, LDL remnants. This range can be further limited to 1.019 to $1.063 \mathrm{~g} / \mathrm{mL}$, which is inclusive of LDL only and can be further subdivided for LDL analysis [91]. LDL particles vary in size, composition and density. They have an average diameter of $18-25 \mathrm{~nm}$ with roughly 3000 lipid molecules in total. Each LDL particle contains one apo B-100 molecule. LDL cholesterol plays a central role in atherogenesis and estimating risk, but LDL cholesterol content does not reflect LDL particle concentration because metabolic processes involving lipids affect lipid size and composition. The relative ratio of cholesterol to triglycerides in LDL can vary greatly [92]. In a study of 118 healthy individuals, the ratio ranged from 1.8 to 11.5 [93]. This significant amount of variability further suggests that LDL-C alone is not sufficient as an indicator of cardiovascular health, since the particle content differs within individual LDL molecules and risk calculators assume a constant cholesterol concentration per molecule of LDL.

Moreover, in individuals with diabetes and metabolic syndrome, although LDL-C levels are normal, the overall lipid profile is pro-atherogenic with high triglycerides and low HDL-C. An added atherogenic factor in those with diabetes and metabolic syndrome is a significant increase in small dense LDL particles. These unique lipid abnormalities pose an increased risk for cardiovascular events, but the normal LDL-C levels can mislead clinicians, who then may not initiate lipid-lowering therapy [92]. A new biomarker may more accurately represent CVD risk and improved management in these patients.

As of 2013, the ASCVD risk calculator has been recommended to predict the 10-year risk of "hard" cardiovascular events, including nonfatal MI, fatal CAD, nonfatal and fatal stroke [94]. The calculator takes into account age, sex, race, blood pressure, total cholesterol, HDL-C, LDL-C, history of diabetes, smoking, hypertensive treatment, aspirin and 3-hydroxy-3-methylglutaryl-coenzyme A reductase (HMGCoA reductase) inhibitors (statins). Based on the score, high- or low-intensity statins are recommended, along with therapy targeting LDL-C [95].

Current guidelines suggest lowering LDL-C as much as possible, as stated by the American Heart Association and the American College of Cardiology [8]. Analysis of data from the Treating to New Targets (TNT) study, a clinical trial in which stable CAD patients with LDL-C above 130 were randomized to $10 \mathrm{mg}$ or $80 \mathrm{mg}$ of atorvastatin per day for about 5 years, has shown that the predictive power of LDL-C is less significant than that of other potential biomarkers such as apoB and non-HDL-C [96]. However, these levels are still not generally suggested as a first-line target for medical therapies.

For the past 30 years, studies have shown that decreasing LDL-C significantly decreases the risk of coronary heart disease (fatal or non-fatal myocardial infarction) [97]. However, CVD risk reduction achieved via lipid-lowering therapy in most clinical studies does not exceed 30\% $[87,98]$. Furthermore, recent meta-analyses have shown that despite achieving target LDL-C levels with lipid-lowering treatment, there is still a high residual risk of coronary artery disease-related events that should be addressed by clinicians $[99,100]$. In the PROVE-IT TIMI 22 trial, $22.7 \%$ of patients still had major cardiovascular events (MCVE) at 2 years of follow-up, despite achieving recommended LDL-C levels, suggesting that a more sensitive biomarker may be necessary to minimize subsequent cardiovascular events [101].

The 2018 AHA/ACA guidelines place emphasis on using maximum-intensity statins to decrease LDL-C as much as possible, as it will further decrease the risk of cardiovascular 
events [78]. Aggressive treatment is inarguably beneficial, but estimated LDL-C using the Friedewald equation underestimates true LDL-C levels, and at low levels of LDL-C, the other variables used in the Freidelwald equation are no longer negligible, making the equation inaccurate and LDL-C levels an unreliable estimate of risk [102].

Additionally, even when achieving recommended LDL-C levels, there is still a high residual risk of cardiovascular-related events [99]. Furthermore, in a 2003 survey by the National Cholesterol Education Program, $62 \%$ of coronary artery disease patients achieved the LDL-C goal of $<100 \mathrm{mg} / \mathrm{DL}$, but only $33 \%$ achieved both the LDL-C and non-HDL-C goals [103]. Combined with the studies showing high risk of subsequent MCVE despite achieving target LDL-C levels, this further supports the theory that LDL cholesterol is an incomplete reflection of MCVE risk and new biomarkers may be beneficial in improving our ability to identify persons at risk for CVD and in improving outcomes for CVD patients.

\subsection{Non-HDL-C as a Biomarker}

A number of clinical studies have shown that as triglycerides rise, especially above $400 \mathrm{mg} / \mathrm{dL}$, the Friedewald equation underestimates the true LDL-C value, interfering with assessment of true cardiovascular risk $[79,104,105]$. Furthermore, nonfasting specimens may be enriched in chylomicrons that contain triglycerides, and this also leads to an underestimation of LDL-C [106].

Recent studies have shown that both apoB and non-HDL cholesterol levels may be equivalent, if not better, indicators of CVD and risk of MCVE compared to LDL-C [107-109]. However, the use of non-HDL-C levels has only been advocated as a first-line target by one association, the National Lipid Association, and apoB levels are only recommended as an alternative to LDL-C by the Canadian Cardiovascular Society [110,111]. The 2019 European Society of Cardiology/European Atherosclerosis Society (ESC/EAS) Guidelines for the management of dyslipidemias support the evaluation and consideration of non-HDL-C and apoB as secondary targets for lipid control [112].

Non-HDL cholesterol is highly correlated with apoB levels but is not always consistent. There is a large variability in apoB levels relative to non-HDL-C. Non-HDL-C is a sum of the cholesterol in atherogenic particles, while apoB is found as a single molecule in each atherogenic particle [113].

ApoB was found to be a better predictor than non-HDL-C in identifying more patients with a compromised cardiovascular profile, according to a population-based sample [114] In addition, a number of differences between non-HDL-C and apoB were noted, such as that increasing levels of non-HDL-C were not associated with a significant increase in the presence of CVD in women. However, an increase in CVD prevalence was noted in both sexes with increasing apoB levels. Moreover, the discriminatory power for the presence of CVD was significantly higher for apoB than for non-HDL-C.

A recent review comparing non-HDL-C and apoB has noted that apoB and non-HDL-C are more accurate measures in ASCVD risk assessment, especially in hypertriglyceridemic individuals, non-fasting individuals, and in those with very low LDL-C concentrations. However, the review did not have enough information to compare apoB and non-HDL-C to each other [115].

A more recent discordance analysis of non-HDL-C versus apoB showed that apoB is the more accurate marker of cardiovascular risk, as apoB can identify elevated numbers of small cholesterol-depleted LDL particles that are neither identified by LDL-C or non-HDL-C. In addition, apoB is better as a target in patients with mild to moderate hypertriglyceridemia (175-880 mg/dL), diabetes, obesity or metabolic syndrome [116].

Overall, little research has been completed to compare apoB and non-HDL-C as predictors of CVD prevalence. From the little research already carried out, it seems that apoB has some advantages, but more work is needed. 


\subsection{ApoB as a Biomarker}

Approximately half of all patients with recurrent coronary syndrome have normal cholesterol levels on standard lipid profiles, and despite having achieved the recommended LDL-C levels, these patients are still at high risk of cardiovascular-related events [117-119]. At the forefront of promising biomarkers lie apoB and non-HDL-C $[117,120]$.

A single molecule of apoB is present in every atherogenic particle; therefore, it has been proposed as a better predictor of cardiovascular events. Standard LDL-C, on the other hand, is a measurement of lipid concentration in lipoprotein particles that are heterogeneous and vary in size, density and lipid content [121]. Over $90 \%$ of total apoB is normally found in LDL particles $[122,123]$. However, since the lipid composition differs between LDL particles, these values do not strongly correlate with LDL cholesterol levels [113,124,125]. Recent studies have shown that apoB has a higher sensitivity and specificity than LDL-C in predicting cardiovascular events, such as myocardial infarction (MI) in both men and women, independent of age [126]. In a population of Japanese patients with established stable CAD documented by coronary artery stenosis exceeding $75 \%$ on coronary angiography, a virtual-histology intravascular ultrasound of the culprit lesions demonstrated greater lesion length and higher plaque volume and percentage of necrotic core volume in patients with high plasma apoB levels when compared to patients with low plasma apoB levels. No correlation was found between apoA1 and the percentage of necrotic core volume of the target coronary artery lesion. In this population, the apoB level was a very good indicator of the size of necrotic core and a potential biomarker for unstable plaque with an advantage over LDL-C [127].

Statins, first-line agents for lipid-lowering, bring about a significantly greater decrease in LDL-C than in apoB levels. This discordance suggests a need for a more precise method of routine lipid monitoring [113].

Additionally, in individuals with LDL-C levels below the median value, apoB can be used to assess MCVE risk, independent of whether or not the atherogenic particles are predominantly LDL-C [16]. This feature is of great significance, especially in diabetic patients, where atherogenicity has a higher level of dependence on lipoproteins other than LDL, such as triglycerides [128]. The inclusivity associated with apoB is one possible explanation for its enhanced predictive capability in determining MCVE risk. ApoB includes LDL-C, VLDL-C, IDL-C and lipoprotein(a), as opposed to LDL cholesterol alone. These other highly atherogenic particles play a key role in CVD and should be accounted for when assessing the risk of subsequent cardiovascular events [129-132]. Furthermore, apoB is a direct measure of the atherogenic particle number rather than cholesterol concentration, which can vary from one atherogenic particle to another as a result of lipid metabolism [113].

Major drawbacks to any transition to standard measuring of apoB include impracticality and cost, in addition to hesitancy by clinicians to welcome this change. Nevertheless, monitoring lipoprotein levels aside from LDL-C may be critical in managing risk and minimizing morbidity and mortality due to CVD in specific subsets of patients such as those with diabetes, as discussed in Section 4 (How Do Pro-Atherosclerotic Risk Factors Affect ApoB levels?) [99]. In addition, without directly measuring apoB levels, atherogenic dyslipoproteinemias, such as remnant lipoprotein disorder, will continue to be underdiagnosed and undertreated [133].

Measuring apoB by immunoassay may be expensive and time-consuming, and its accuracy may vary [134]. As an alternative, circulating apoB is often estimated using an algorithm, but these values are only approximations based on lipid variables such as the total cholesterol and HDL [135] or LDL and triglycerides [136], and their clinical relevance has not been confirmed.

Interestingly, de Vries et al. have shown that binding of apoB-containing lipoproteins to circulating erythrocytes, detected by flow cytometry, is associated with lower cardiovascular mortality. This inverse relationship between atherosclerosis and levels of erythrocyteapoB binding can be considered as another means to use apoB as a biomarker [137]. 


\subsection{ApoB to ApoA1 Ratio as a Biomarker}

While $\mathrm{ApoB}$ acts as a major transporter for all atherogenic particles, apoA1 is an antiatherogenic lipoprotein responsible for transporting cholesterol within HDL-C [138-140]. ApoA1 activates lecithin-cholesterol acyltransferase (LCAT), an enzyme that esterifies plasma cholesterol and increases the cholesterol carrying capacity of HDL (Figure 3). The ratio of apoB/apoA1 reflects the balance between the two opposing forces and has been proven to be an accurate indicator of CVD risk. The greater the ratio, the more cholesterol is circulating in the plasma and being deposited into the arterial wall [141].

Multiple prospective studies, including the INTERHEART study and Apolipoproteinrelated Mortality RISK (AMORIS) trial, have shown a positive linear association between any risk of a cardiovascular event and increasing apoB/apoA1 ratio [126,142-144]. In the AMORIS study, subjects with a first cardiovascular event prior to age 50 exhibited elevated total cholesterol, triglycerides, LDL-C, glucose, apoB, and apoB/apoA-1 ratio compared to controls up to 20 years before the cardiac event [145]. This supports treating and remedying the discrepancy in lipoprotein levels between persons with a high risk for a cardiovascular event at a young age and those without this risk.

Sierra-Johnson et al. used data from The Third National Health and Nutrition Examination Survey (NHANES III) combined with National Death Index information and laboratory analysis of lipids/apolipoproteins in a prospective study of a representative multi-ethnic sample in the United States of America to evaluate cardiovascular risk predictors [146]. When comparing the accuracy of the prediction of coronary heart disease mortality based on apolipoprotein levels, they found that both apoB and the apoB/apoA1 ratio proved better than traditional cholesterol markers. When testing the superiority of apoB /apoA1 over apoB alone, they found that the difference was not statistically significant when adjusting for risk factors, such as obesity, smoking, dyslipidemia, hypertension, diabetes, and high C-reactive protein (CRP). Therefore, there was no proven benefit of using apoB/apoA1 over apoB alone. They thus concluded that apoB is the primary underlying source of the high predictive power of the apoB/apoA1 ratio and the lesser importance of apoA1 in the assessment of risk. On the other hand, the use of apoB/apoA1 has other benefits. The apolipoprotein ratio is associated with insulin resistance in non-diabetic subjects and can therefore be helpful in patients whose phenotypes are independent of apoB [147].

\subsection{When Does ApoB Show an Advantage over HDL-C?}

A number of studies have shown that under specific circumstances, apoB alone is a better predictor of MCVE than the apoB/apoA1 ratio. Data from the INTERHEART study, a global study of over 12,000 cases of first acute myocardial infarction and over 14,000 ageand sex-matched controls, showed that the power of apoB to predict myocardial infarction was consistently higher than non-HDL-C or LDL-C up to age 70. An analysis of patients enrolled in single-center, cross-sectional community-based studies at the University of Pennsylvania found that in Caucasians with type 2 diabetes, plasma apoB, but not LDL-C, may be an indicator of coronary artery calcification beyond traditional risk factors [148]. The apoB/apoA1 ratio was better than the non-HDL-C/HDL-C ratio in predicting the presence of carotid plaques in patients on peritoneal dialysis [149]. The apoB/apoA1 ratio also showed improved accuracy over TC/HDL-C in predicting adverse cardiovascular events in a prospective study of patients with established coronary heart disease (CHD) [144].

In summary, both apoB and apoB/apoA1 are better than traditional cholesterol risk markers for CVD under some circumstances. The use of apoB or apoB/apoA1 holds promise for both evaluating risk and targeting treatment; however, further research is needed to establish whether the ratio adds value over apoB alone [150]. 


\section{How Do Pro-Atherosclerotic Risk Factors Affect ApoB Levels?}

\subsection{ApoB, CVD and Demographics}

Cardiovascular risk prediction is of high importance for clinicians and patients as a way to assess the risk of developing future symptomatic CVD, thereby allowing for preventive interventions to be instituted in those patients who are most likely to benefit. Accurate estimates of CVD risk are sought in hopes of decreasing CVD morbidity and mortality [151-153]. CVD risk is determined by an accumulation of non-modifiable and potentially modifiable factors throughout a lifetime [153-158]. Often, multiple risks factors and comorbidities are present in an individual, and the progression of CVD is accelerated by their interaction, not only additively but also synergistically $[159,160]$.

ApoB levels generally do not differ across ethnicities, but the amount of oxidized phospholipid carried per apoB particle is higher in African Americans than in Caucasians or Hispanics, possibly indicating more atherogenic particles in African Americans [161,162]. ApoB levels are lower on average in females than males, and catabolism occurs at a higher rate in females [163]. In a Swedish study, the mean apoB concentration was $1.31 \pm 0.35 \mathrm{~g} / \mathrm{L}$ in males versus $1.22 \pm 0.36 \mathrm{~g} / \mathrm{L}$ in females [164]. ApoB levels are higher in women after menopause, probably because of a slower catabolic rate [165].

\subsection{Specific Risk Factors: Body Weight, Hypertension, Diabetes}

In general, a number of known CVD risk factors have a stronger correlation to apoB levels than to LDL-C and other biomarkers. Patients with normal levels of non-HDLcholesterol, but high levels of apoB have a higher BMI, waist circumference, systolic blood pressure, fasting insulin and C-reactive protein-all important established risk factors for CVD [159].

A large anonymized clinical laboratory analysis of over 30,000 men and women not on lipid-lowering medications showed that a change in body weight was associated with significant changes in apoB and non-HDL cholesterol that provided information beyond triglyceride and LDL-C measures [166]. A small study of 44 normal weight and 39 obese subjects, all with high LDL-C, comparing dietary intervention with 7 days of either a diet enriched in polyunsaturated fats or saturated fatty acids, showed that the polyunsaturated fat diet lowered both LDL-C and apoB and the BMI $\times$ diet interaction showed less improvement in LDL-C and apoB in the obese subjects [167]. A recent metaanalysis with combined data on 335 overweight and obese healthy or hyperlipidemic subjects on calorie-restricted diets found significant reductions in apoB concentrations with $6-12 \%$ weight loss. In non-weight loss dietary comparisons, the Mediterranean diet was most closely associated with lower plasma apoB [168].

The accuracy of atherogenic risk attributable to apoB varies at different ages. Although the risk for a coronary event increases with age, the cardiovascular risk associated with the apoB level decreases with age, indicating that apoB may be a better biomarker for CVD in younger patients than in older ones. Results of the CARDIA (Coronary Artery Risk Development in Young Adults) study showed that in persons followed for approximately 25 years beginning as young adults (mean age of 25 years), high apoB at a young age was strongly associated with coronary calcifications, a surrogate CVD risk marker, in middle age (mean age 50 years) [169]. Multiple other biomarkers of cardiovascular risk are also noted to be more accurate in younger patients than in older ones. These include total cholesterol, LDL-C, non-HDL-C, HDL-C and apoA1 [170].

ApoB may be useful in predicting CVD risk in states of insulin resistance such as metabolic syndrome and type 2 diabetes [148,171,172]. ApoB is highly associated with type 2 diabetes and research has shown that apoB levels may be a risk factor for type 2 diabetes $[173,174]$. ApoB quantification is especially useful in patients with insulin resistance and elevated triglyceride levels above $150 \mathrm{mg} / \mathrm{dL}$, where the Friedewald equation becomes inaccurate and loses its ability to provide a measure of atherogenic load [80-83,175,176].

In non-diabetic patients, apoB - but not LDL-C—corresponded positively with dysfunctional white adipose tissue and delayed clearance of fat, hyperinsulinemia, insulin 
resistance, and activation of the IL- $1 \beta$ system, all of which are known risk factors for type 2 diabetes [168,177]. In fact, epidemiological studies have shown that apoB predicts the development of type 2 diabetes as much as 3-10 years in advance of clinical onset [178-180].

\subsection{The Clinical Significance of Small Dense LDL}

Small dense LDL particles are associated with excessive CVD risk [181,182]. Among the properties of these small dense LDL particles that make them atherogenic are their ease of penetration into the arterial wall, poor binding to LDL receptors and prolonged circulation time in the bloodstream [183]. Small dense LDLs have enhanced susceptibility to damage from both oxidation and glycation and their level in plasma is highly correlated with plasma triglyceride and apoB concentrations [184-186].

Plasma levels of small dense LDL particles may be elevated in patients with inflammatory diseases such as rheumatoid arthritis and systemic lupus erythematosus, which also carry increased CVD risk $[187,188]$. They are also elevated in states of hyperglycemia such as gestational diabetes, type 2 diabetes and diabetic retinopathy [189-192]. Viktorinova and colleagues found that the level of small dense LDL in persons with diabetes can be estimated based on the ratio of LDL/apoB such that there is an inverse relationship between these parameters [193]. Since LDL and apoB are more routinely measured than small dense LDL, calculating this ratio can be applied as a CVD risk measure reflecting small dense LDL prevalence [194]. Zheng et al. [195] link compromised clearance of apoB-containing lipoproteins to both hypertriglyceridemia and a shift in LDL composition favoring small dense particles, possibly through a pathway driven by apoC-III. Small dense LDL levels also correlate with the occurrence of peripheral arterial disease [196-198].

\section{ApoB as a Target of CVD Treatment}

While apoB may be an applicable target for decreasing risk associated with CVD, only a handful of treatments have been designed to impact the levels of this protein (Table 1). Recent evidence has shown that patients with autoantibodies that directly target apoB have, in fact, lower rates of CVD. Specifically, patients who had plasma levels with a high concentration of antibodies targeting native peptide 210 of apoB-100 had a $45 \%$ lower risk of developing a myocardial infarction. This suggests that apoB is not only a prognostic factor but also an important target for minimizing disease progression [199].

Table 1. Lipid-lowering therapies that reduce ApoB.

\begin{tabular}{|c|c|c|}
\hline Therapy & Type of Compound & Mechanism of Effect on ApoB \\
\hline statins & $\begin{array}{c}\text { Competitive inhibitors of HMG-CoA } \\
\text { reductase }\end{array}$ & $\begin{array}{l}\text { Lower apoB concentration by decreasing entry of } \\
\text { apoB-containing lipoproteins LDL and VLDL } \\
\text { into plasma }\end{array}$ \\
\hline $\begin{array}{c}\text { anacetrapib } \\
\text { (development discontinued) }\end{array}$ & Small molecule oxazolidinone & $\begin{array}{l}\text { Potent selective CETP inhibitor. Reduces } \\
\text { apoB-containing lipoprotein particles }\end{array}$ \\
\hline niacin & Nicotinic acid (vitamin B3) & $\begin{array}{l}\text { Modulates liver synthesis of triglycerides, } \\
\text { limiting VLDL assembly, resulting in } \\
\text { intrahepatic apo B degradation }\end{array}$ \\
\hline evolocumab and alirocumab & $\begin{array}{l}\text { Fully human anti-PCSK9 monoclonal } \\
\text { antibodies }\end{array}$ & $\begin{array}{c}\text { PCSK9 inhibitors increase hepatic LDL receptors, } \\
\text { which remove apoB-containing LDL particles } \\
\text { from the circulation. Lp(a) also decreased, } \\
\text { mechanism not understood }\end{array}$ \\
\hline $\begin{array}{c}\text { mipomersen } \\
\text { (development discontinued) }\end{array}$ & $\begin{array}{c}\text { Synthetic phosphorothioate antisense } \\
\text { oligonucleotide apoB inhibitor }\end{array}$ & $\begin{array}{l}\text { Prevents translation of the apoB mRNA into } \\
\text { protein, leading to decreased VLDL and LDL }\end{array}$ \\
\hline lomitapide & $\begin{array}{l}\text { Small molecule that binds directly to and } \\
\text { inhibits MTP }\end{array}$ & $\begin{array}{c}\text { Inhibition of MTP in hepatocytes and enterocytes } \\
\text { by lomitapide reduces plasma levels of all } \\
\text { ApoB-containing lipoproteins. }\end{array}$ \\
\hline
\end{tabular}


Table 1. Cont.

\begin{tabular}{|c|c|c|}
\hline Therapy & Type of Compound & Mechanism of Effect on ApoB \\
\hline dabigatran & $\begin{array}{l}\text { Novel, synthetic, specific, non-peptide } \\
\text { thrombin inhibitor }\end{array}$ & $\begin{array}{c}\text { Antithrombotic effect due to binding } \\
\text { competitively to the active site on human } \\
\text { thrombin. ApoB lowering is a pleiotropic effect, } \\
\text { mechanism unclear. }\end{array}$ \\
\hline bempedoic acid & $\begin{array}{l}\text { 8-hydroxy-2,2,14,14- } \\
\text { tetramethylpentadecaned-ioic } \\
\text { acid }\end{array}$ & $\begin{array}{c}\text { Inhibits ATP-citrate lyase in the liver, which } \\
\text { decreases liver cholesterol synthesis and reduces } \\
\text { serum LDL levels by upregulating LDL } \\
\text { receptors. }\end{array}$ \\
\hline evinacumab & $\begin{array}{l}\text { Fully human monoclonal antibody } \\
\text { directed against ANGPTL3 }\end{array}$ & $\begin{array}{l}\text { Antagonizes ANGPTL3-mediated inhibition of } \\
\text { lipoprotein lipase and } \\
\text { endothelial lipase, increasing clearance of } \\
\text { apoB-containing lipoproteins. }\end{array}$ \\
\hline fibrates & $\begin{array}{c}\text { Amphipathic carboxylic acids that act as } \\
\text { peroxisome proliferator receptor } \alpha \\
\text { agonists }\end{array}$ & $\begin{array}{l}\text { Reduce plasma triglycerides by inhibiting their } \\
\text { hepatic synthesis and increasing their catabolism. } \\
\text { Lower LDL-C, non-HDL-C and apoB. }\end{array}$ \\
\hline inclisiran & $\begin{array}{c}\text { siRNA conjugated to triantennary } \\
\text { N-acetylgalactosamine carbohydrates }\end{array}$ & $\begin{array}{c}\text { Inhibits PCSK9, thereby reducing levels of } \\
\text { apoB-containing lipoproteins. }\end{array}$ \\
\hline
\end{tabular}

Lipoprotein classes constantly exchange their lipid components. One of the most crucial proteins in the lipid metabolism pathway is the cholesteryl ester transfer protein (CETP), a hydrophobic glycated protein that facilitates the exchange of cholesteryl esters and triacylglycerol between HDL and apoB-containing lipoproteins [200-202]. Since CETP results in the formation of more apoB-containing triglyceride-rich lipoprotein particles such as VLDL and is inversely associated with HDL particle size and composition, it is considered atherogenic. The inhibition of CETP and cholesteryl ester transfer was expected to increase HDL-C whilst decreasing LDL-C and other particles that harbor apoB, thereby lowering the risk of cardiovascular-related events. However, clinical results were, at first, surprising [203,204]. Three CETP inhibitors, torcetrapib, dalcetrapib and evacetrpib, when tested in humans, which either increased cardiovascular risk or were neutral, while a fourth, anacetrapib, showed modest cardiovascular benefit [205-208]. Of these drugs, only anacetrapib, in the phase 3 randomized, placebo-controlled REVEAL trial (Randomized Evaluation of the Effects of Anacetrapib through Lipid-Modification), showed a 9\% relative risk reduction in major coronary events in persons with pre-existing ASCVD after a median of 4 years of treatment $[209,210]$. This effect of anacetrapib has been attributed to decreased LDL-C accompanied by a reduction in apoB-containing lipoprotein particles but may also be explained by a decrease in small VLDL particles [211]. Furthermore, anacetrapib may increase the number of cell surface LDL receptors, thus increasing clearance of apoBcontaining lipoproteins. Unfortunately, anacetrapib induces excess lipid accumulation in adipose tissue, and so it will not be developed further. Further studies are certainly necessary to refine our knowledge of CETP and improve targeting of this protein in ways that may optimally address cardiovascular risk. A study by Ference et al. in 2019 [212] shed light on the importance of apoB particle number in determining CHD risk. They looked at data on 654,783 people, 91,129 of whom had CHD, and found that triglyceride-lowering variants in the lipoprotein lipase gene and LDL-C-lowering variants in the LDL receptor gene each lessened the cardiovascular event risk to a similar degree when measured based on absolute change in apoB. This suggests that it is the net absolute change in the number of apoB-containing lipoprotein particles rather than the cholesterol content of the LDL particle that determines CHD risk. The implication of this result is that lowering LDL-C by reducing the amount of cholesterol in each particle while not decreasing the particle number will not be effective, even though LDL-C in the lipid profile goes down.

An agent widely utilized to regulate abnormalities in the metabolism of plasma lipids and lipoproteins as well as in the treatment of ASCVD is the B-complex vitamin niacin [213]. 
Niacin is beneficial in reducing triglycerides and apoB-containing lipoproteins, including VLDL and LDL, through two main mechanisms. One way in which niacin regulates circulating triglycerides and VLDL is by decreasing free fatty acid mobilization from adipose tissue stores. In addition, niacin acts as a noncompetitive inhibitor of hepatocyte diacylglycerol acyltransferase-2, a critical enzyme in the synthesis of triglycerides. With less triglyceride availability, intracellular hepatic apoB degradation accelerates, and this leads to decreased secretion of VLDL and LDL particles by the liver. Niacin improves multiple lipid parameters, and its lipid-altering efficacy is comparable to statins; however, it is underutilized due to the adverse experience of flushing [214-219]. This adverse reaction is often mitigated via laropiprant, a prostaglandin D2 receptor (DP1) antagonist that reduces niacin-induced flushing [220,221]. It has been combined with extended-release niacin into a fixed-dose tablet that improves key lipid parameters associated with increased CHD risk in patients with primary hypercholesterolemia or mixed dyslipidemia [222-225].

Among the human monoclonal antibodies that have established efficacy and safety in achieving desirable LDL-C targets are evolocumab and alirocumab [226]. These PCSK9 inhibitors are used to treat primary hyperlipidemia and have been found to reduce myocardial infarction and stroke in persons with established CVD [227,228]. The PCSK9 enzyme enhances degradation of the LDL receptor; therefore, its inhibition allows for greater accumulation of this receptor, enhancing clearance of apoB-containing lipoproteins and reducing the LDL and apoB particle number $[229,230]$. It has been suggested that if the target LDL-C level is not achieved with the maximum tolerated statin dose, the next adjunctive therapy to add after ezetimibe would be a PCSK9 inhibitor [231,232].

The inhibition of apoB production may be an effective therapeutic against CVD since fewer apoB particles would lead to lowering of LDL-C and VLDL-C $[233,234]$. In addition, apoB has been shown to play a key role in LDL-C-induced dysfunction of vascular endothelium, leading the way to apoB-targeted therapy for ischemic CVD [235]. One strategy to reduce apoB is through antisense oligonucleotide technology. Mipomersen, a 20-base-pair single-stranded DNA oligonucleotide that binds to the specific mRNA sequence encoding human apoB-100, had great promise in human trials; unfortunately, liver toxicity associated with this therapy led to its discontinuation [236,237].

Lomitapide, a small molecule microsomal triglyceride transfer protein (MTP) inhibitor, exerts its effects in the liver by binding directly to MTP in the endoplasmic reticulum of hepatocytes and enterocytes. MTP is an intracellular protein that catalyzes the transfer of triglycerides onto apoB within the liver in the formation of VLDL [238]. Lomitapide, via its effect on MTP, prevents the synthesis and secretion of VLDL, thereby causing a decrease in the number of secreted apoB-containing lipoproteins [239-241]. It is administered orally and is only indicated for the treatment of homozygous familial hypercholesterolemia as an adjunct to a low-fat diet and other lipid-lowering treatments. Similar to mipomersen, lomitapide has many adverse effects, which has limited its use and tolerability. Trials have shown evidence of elevated transaminases and gastrointestinal side effects, leading to early discontinuation of the drug by a large number of patients. Mipomersen is also a CYPP3A4 inhibitor, and its use is therefore limited in patients taking other medications metabolized by this enzyme [242].

In addition, dabigatran, a small molecule oral anticoagulant that binds competitively and selectively to the catalytic site of thrombin and is used for the prevention of ischemic stroke in atrial fibrillation, has surprisingly been found to decrease apoB levels by as much as $7 \%[243,244]$. Although the exact cause of this pleiotropic effect has yet to be elucidated, Joseph et al. suspect it may be due to competing activity of microsomal carboxylesterases. This unexpected lowering of apoB has the potential to explain the success of dabigatran in the reduction of stroke $[244,245]$. Further research into the mechanism by which this drug decreases apoB levels may support the importance of apoB in the management of hyperlipidemia.

Bempedoic acid is an inhibitor of hepatic ATP citrate lyase, an enzyme that functions upstream of HMG CoA reductase. The inhibition of ATP citrate lyase decreases intracellular 
cholesterol biosynthesis and results in LDL receptor upregulation on hepatocytes. This increases the liver uptake of LDL particles and reduces circulating LDL-C, non-HDL-C and apoB levels [246,247].

Another therapeutic approach to CVD is the inhibition of angiopoietin-like protein 3 (ANGPTL3), a secretory glycoprotein that reversibly inhibits the catalytic activity of lipoprotein lipase, the rate-limiting enzyme in triglyceride hydrolysis [248]. Evinacumab, a fully human IgG monoclonal antibody against ANGPTL3, enhances VLDL catabolism, thus lowering LDL, VLDL and triglycerides [249,250]. Evinacumab reduces apoB levels by increasing apoB-containing lipoprotein clearance. It was recently approved by the FDA as an adjunct to other LDL-C-lowering therapies for homozygous familial hypercholesterolemia [251].

Several drugs with primary targets other than apoB can lower apoB incidentally. Fibrates, which reduce plasma triglycerides by inhibiting their hepatic synthesis, also reduce apoB levels by 10 to $20 \%$ [252,253]. Gemcabene, a lipid-lowering drug in development that works by decreasing apoC-III and thus increasing VLDL clearance, also lowers apoB, LDL-C and CRP [254].

\section{Future Perspectives}

New therapies that lower apoB are on the horizon and, despite the problems with mipomersen, most promising is the application of antisense technology. Gene silencing with antisense oligonucleotides is being used to directly interfere with PCSK9 production. Inclisiran is a synthetic, double-stranded siRNA that yielded a sustained reduction of over $20 \%$ in apoB in phase 2 human trials [255].

When currently available lipid-lowering therapy is administered, the maximum decrease in risk of MCVE is $30-40 \%$. However, poor compliance is a major obstacle in many patients $[256,257]$. This widespread issue can be resolved with a vaccine exerting long-term effects $[258,259]$. Antigen-specific immunoprotection via vaccination is a recent potential approach to prevention and treatment of chronic diseases [260]. Mechanisms include the production of antibodies, T-cell anergy, and the induction of regulatory T cells [261]. The specificity of apoB peptides is key in avoiding side effects by host defenses. The two forms of atherosclerosis vaccines being developed are antibody-inducing and regulatory $\mathrm{T}$ cell-inducing. Vaccines based on apoB-derived peptides have shown promising results by targeting an immune response via regulatory $\mathrm{T}$ cells and reducing atherosclerotic lesions in mice [262]. Treating CVD with vaccines will face many challenges but holds a lot of promise. Years of research lie ahead of us in exploring the role vaccination could play in the treatment of CVD, as well as other inflammatory diseases [263].

\section{Conclusions}

Cardiovascular disease remains the leading cause of death worldwide [264]. Recent data have shown a decline in mortality from CHD in the United States of America, but the rate of decline is decelerating and, in younger adults under age 45 , there is a lack of progress in reducing cardiovascular deaths $[265,266]$. In this younger group, a rise in diabetes mellitus and obesity may be hindering improvement in cardiovascular mortality [267]. It has been predicted that by the year 2035, over half of the US population will suffer from some form of cardiovascular disease and projected annual costs may exceed 1 trillion dollars [268]. Pharmacotherapy based on cholesterol management and lipid profile is the cornerstone of treatment and prevention. However, even with lipid-lowering therapy, the absolute risk of cardiovascular-related events remains elevated, and many patients do not achieve lipid goals, most frequently those at high cardiovascular risk $[269,270]$. Current American guidelines focus on LDL-C-targeted therapy; however, as shown in this review, there is a preponderance of data supporting a role for apoB in cardiovascular risk prediction. ApoB has been proposed as a better predictor of MCVE because a single molecule is found in every atherogenic particle and LDL-C levels alone can miss elevated particle numbers [271]. 
The evaluation of apoB mass in plasma by mass spectrometry allows the characterization of the proteome of the particles. With mass spectrometry, detection of individual peptide components and comparison of molar ratios may improve risk prediction. Data are supplied on individual subfractions within apoB-containing particles and the extent of oxidation of phospholipids on apoB particles can be determined [192,272,273]. The method is antibody-independent and can be automated. Mass spectrometry was applied in a study by Bodde et al. that found a strong association between plasma levels of apoA1, apoB, and the apoB/apoA1 ratio and first ST-segment elevation myocardial infarction [274].

The wide acceptance of LDL-C coupled with the added expense and complication of measuring apoB has thus far prevented a major shift toward clinical application of plasma apoB at the point-of-care $[275,276]$. This may change as standardization of apoB measurement improves and as data supporting the benefits of apoB in cardiovascular health assessment accumulate $[277,278]$.

Author Contributions: A.B.R. and J.B. conceptualized the topic of the review. The manuscript was drafted by J.B., A.B.R., S.A. and A.E.; critically revised by J.D.L., L.J.K. and A.D.G. Figures were designed by A.D.G. and L.J.K. A.B.R. revised the manuscript. All authors have read and agreed to the published version of the manuscript.

Funding: This research received no external funding.

Acknowledgments: In memory of Elizabeth Daniell and Lt. Col. E.L. Daniell. We thank Robert Buescher for his dedication to medical research.

Conflicts of Interest: Authors declare that they have no conflict of interest or competing interests.

\section{References}

1. Roth, G.A.; Forouzanfar, M.H.; Moran, A.E.; Barber, R.; Nguyen, G.; Feigin, V.L.; Naghavi, M.; Mensah, G.A.; Murray, C.J. Demographic and epidemiologic drivers of global cardiovascular mortality. N. Engl. J. Med. 2015, 372, 1333-1341. [CrossRef] [PubMed]

2. Fuster, V.; Voûte, J. MDGs: Chronic diseases are not on the agenda. Lancet 2005, 366, 1512-1514. [CrossRef]

3. Benjamin, E.J;; Muntner, P.; Alonso, A.; Bittencourt, M.S.; Callaway, C.W.; Carson, A.P.; Chamberlain, A.M.; Chang, A.R.; Cheng, S.; Das, S.R.; et al. Heart disease and stroke statistics-2019 update: A report from the American heart association. Circulation 2019, 139, e56-e528. [PubMed]

4. Gazzola, K.; Reeskamp, L.; van den Born, B.J. Ethnicity, lipids and cardiovascular disease. Curr. Opin. Lipidol. 2017, 28, 225-230. [CrossRef] [PubMed]

5. Szuszkiewicz-Garcia, M.M.; Davidson, J.A. Cardiovascular disease in diabetes mellitus, risk factors and medical therapy. Endocrinol. Metab. Clin. N. Am. 2014, 43, 25-40. [CrossRef] [PubMed]

6. Silverio, A.; Cavallo, P.; De Rosa, R.; Galasso, G. Big Health Data and Cardiovascular Diseases: A Challenge for Research, an Opportunity for Clinical Care. Front. Med. 2019, 6, 36. [CrossRef] [PubMed]

7. Alkhalil, M. Mechanistic Insights to Target Atherosclerosis Residual Risk. Curr. Probl. Cardiol. 2019, 46, 100432. [CrossRef]

8. Arnett, D.K.; Blumenthal, R.S.; Albert, M.A.; Buroker, A.B.; Goldberger, Z.D.; Hahn, E.J; Himmelfarb, C.D.; Khera, A.; LloydJones, D.; McEvoy, J.W.; et al. 2019 ACC/AHA Guideline on the Primary Prevention of Cardiovascular Disease: A Report of the American College of Cardiology / American Heart Association Task Force on Clinical Practice Guidelines. J. Am. Coll. Cardiol. 2019, 74, 1376-1414. [CrossRef]

9. Fruchart, J.C.; Sacks, F.; Hermans, M.P.; Assmann, G.; Brown, W.V.; Ceska, R.; Chapman, M.J.; Dodson, P.M.; Fioretto, P.; Ginsberg, H.N.; et al. The Residual Risk Reduction Initiative: A call to action to reduce residual vascular risk in patients with dyslipidemia. Am. J. Cardiol. 2008, 102, 1K-34K. [CrossRef]

10. Trompet, S.; Packard, C.J.; Jukema, J.W. Plasma apolipoprotein-B is an important risk factor for CVD, and its assessment should be routine clinical practice. Curr. Opin. Lipidol. 2018, 29, 51-52. [CrossRef]

11. Libby, P.; Tabas, I.; Fredman, G.; Fisher, E.A. Inflammation and its resolution as determinants of acute coronary syndromes. Circ. Res. 2014, 114, 1867-1879. [CrossRef]

12. Maguire, E.M.; Pearce, S.W.A.; Xiao, Q. Foam Cell Formation: A New Target for Fighting Atherosclerosis and Cardiovascular Disease. Vascul. Pharmacol. 2019, 112, 54-71. [CrossRef] [PubMed]

13. Ginsberg, H.N. Lipoprotein Physiology. Endocrinol. Metab. Clin. North Am. 1998, 27, 503-519. [CrossRef]

14. Olofsson, S.O.; Borèn, J. Apolipoprotein B: A clinically important apolipoprotein which assembles atherogenic lipoproteins and promotes the development of atherosclerosis. J. Intern. Med. 2005, 258, 395-410. [CrossRef] [PubMed]

15. Von Zychlinski, A.; Williams, M.; McCormick, S.; Kleffmann, T. Absolute quantification of apolipoproteins and associated proteins on human plasma lipoproteins. J. Proteom. 2014, 106, 181-190. [CrossRef] [PubMed] 
16. Morita, S.Y. Metabolism and Modification of Apolipoprotein B-Containing Lipoproteins Involved in Dyslipidemia and Atherosclerosis. Biol. Pharm. Bull. 2016, 39, 1-24. [CrossRef]

17. Herscovitz, H.; Derksen, A.; Walsh, M.T.; McKnight, C.J.; Gantz, D.L.; Hadzopoulou Cladaras, M.; Zannis, V.; Curry, C.; Small, D.M. The N-terminal $17 \%$ of apoB binds tightly and irreversibly to emulsions modeling nascent very low density lipoproteins. J. Lipid Res. 2001, 42, 51-59. [CrossRef]

18. Pulai, J.I.; Neuman, R.J.; Groenewegen, A.W.; Wu, J.; Schonfeld, G. Genetic heterogeneity in familial hypobetalipoproteinemia: Linkage and non-linkage to the apoB gene in Caucasian families. Am. J. Med. Genet. 1998, 76, 79-86. [CrossRef]

19. Law, S.W.; Lackner, K.J.; Hospattankar, A.V.; Anchors, J.M.; Sakaguchi, A.Y.; Naylor, S.L.; Brewer, H., Jr. B. Human apolipoprotein B-100: Cloning, analysis of liver mRNA, and assignment of the gene to chromosome 2. Proc. Natl. Acad. Sci. USA 1985, 82, 8340-8344.

20. Fisher, E.A.; Ginsberg, H.N. Complexity in the secretory pathway: The assembly and secretion of apolipoprotein B containing lipoproteins. J. Biol. Chem. 2002, 277, 17377-17380.

21. Chan, L. Apolipoprotein B, the Major Protein Component of Triglyceride-rich and Low Density Lipoproteins. J. Biol. Chem. 1992, 267, 25621-25624. [CrossRef]

22. Nakajima, K.; Nakano, T.; Tokita, Y.; Nagamine, T.; Inazu, A.; Kobayashi, J. Postprandial lipoprotein metabolism; VLDL vs chylomicrons. Clin. Chim. Acta 2011, 412, 1306-1318. [CrossRef]

23. Powell, L.M.; Wallis, S.C.; Pease, R.J.; Edwards, Y.H.; Knott, T.J.; Scott, J. A novel form of specific RNA processing produces apolipoprotein B-48 in intestine. Cell 1987, 50, 831-840. [CrossRef]

24. Davidson, N.O.; Shelness, G.S. Apolipoprotein B: mRNA editing, lipoprotein assembly, and presecretory degradation. Annu. Rev. Nutr. 2000, 20, 169-193. [CrossRef] [PubMed]

25. Avramoglu, R.K.; Adeli, K. Hepatic regulation of apolipoprotein B. Rev. Endocr. Metab. Disord. 2004, 5, 293-301. [CrossRef] [PubMed]

26. Doonan, L.M.; Fisher, E.A.; Brodsky, J.L. Can modulators of apolipoproteinB biogenesis serve as an alternate target for cholesterollowering drugs? Biochim. Biophys. Acta Mol. Cell. Biol. Lipids 2018, 1863, 762-771. [CrossRef] [PubMed]

27. Rustaeus, S.; Lindberg, K.; Stillemark, P.; Claesson, C.; Asp, L.; Larsson, T.; Borén, J.; Olofsson, S.O. Assembly of very low density lipoprotein: A two-step process of apolipoprotein B core lipidation. J. Nutr. 1999, 129, 463S-466S. [CrossRef] [PubMed]

28. Kane, J.P. Apolipoprotein B: Structural and metabolic heterogeneity. Annu. Rev. Physiol. 1983, 45, 637-650. [CrossRef] [PubMed]

29. Whitfield, A.J.; Barrett, P.H.; van Bockxmeer, F.M.; Burnett, J.R. Lipid disorders and mutations in the APOB gene. Clin. Chem. 2004, 50, 1725-1732. [CrossRef]

30. Burnett, J.R.; Barrett, P.H.R. Apolipoprotein B metabolism: Tracer kinetics, models, and metabolic studies. Crit. Rev. Clin. Lab. Sci. 2002, 39, 89-137. [CrossRef]

31. Segrest, J.P.; Jones, M.K.; Mishra, V.K.; Anantharamaiah, G.M.; Garber, D.W. ApoB-100 has a pentapartite structure composed of three amphipathic alpha-helical domains alternating with two amphipathic beta-strand domains. Detection by the computer program LOCATE. Arterioscler. Thromb. 1994, 14, 1674-1685. [CrossRef] [PubMed]

32. Blasiole, D.A.; Davis, R.A.; Attie, A.D. The physiological and molecular regulation of lipoprotein assembly and secretion. Mol. Biosyst. 2007, 3, 608-619. [CrossRef] [PubMed]

33. Williams, K.J.; Fisher, E.A. Apolipoprotein B: The crucial protein of atherogenic lipoproteins. In Atherosclerosis: Risks, Mechanisms, and Therapies; Wang, H., Patterson, C., Eds.; Wiley Blackwell: Hoboken, NJ, USA, 2015; pp. 291-305.

34. Jiang, Z.G.; Liu, Y.; Hussain, M.M.; Atkinson, D.; McKnight, C.J. Reconstituting initial events during the assembly of apolipoprotein B-containing lipoproteins in a cell-free system. J. Mol. Biol. 2008, 383, 1181-1194. [CrossRef]

35. Manchekar, M.; Kapil, R.; Sun, Z.; Segrest, J.P.; Dashti, N. Relationship between Amphipathic $\beta$ Structures in the $\beta 1$ Domain of Apolipoprotein B and the Properties of the Secreted Lipoprotein Particles in McA-RH7777 Cells. Biochemistry 2017, 56, 4084-4094. [CrossRef]

36. Biterova, E.I.; Isupov, M.N.; Keegan, R.M.; Lebedev, A.A.; Sohail, A.A.; Liaqat, I.; Alanen, H.I.; Ruddock, L.W. The crystal structure of human microsomal triglyceride transfer protein. Proc. Natl. Acad. Sci. USA 2019, 116, 17251-17260. [CrossRef]

37. Segrest, J.P.; Jones, M.K.; De Loof, H.; Dashti, N. Structure of apolipoprotein B100 in low density lipoproteins. J. Lipid Res. 2001, 42, 1346-1367. [CrossRef]

38. Dixon, J.L.; Ginsberg, H.N. Regulation of hepatic secretion of apolipoprotein B-containing lipoproteins: Information obtained from cultured liver cells. J. Lipid Res. 1993, 34, 167-179. [CrossRef]

39. Shelness, G.S.; Ingram, M.F.; Huang, X.F.; DeLozier, J.A. Apolipoprotein B in the Rough Endoplasmic Reticulum: Translation, Translocation and the Initiation of Lipoprotein Assembly. J. Nutr. 1999, 129, 456S-462S.

40. Zhou, M.; Fisher, E.A.; Ginsberg, H.N. Regulated Co-translational ubiquitination of apolipoprotein B100. A new paradigm for proteasomal degradation of a secretory protein. J. Biol. Chem. 1998, 273, 24649-24653. [CrossRef]

41. Rutledge, A.C.; Qiu, W.; Zhang, R.; Kohen-Avramoglu, R.; Nemat-Gorgani, N.; Adeli, K. Mechanisms targeting apolipoprotein B100 to proteasomal degradation: Evidence that degradation is initiated by BiP binding at the $\mathrm{N}$ terminus and the formation of a p97 complex at the C terminus. Arterioscler. Thromb. Vasc. Biol. 2009, 229, 579-585. [CrossRef] [PubMed]

42. Koerner, C.M.; Roberts, B.S.; Neher, S.B. Endoplasmic reticulum quality control in lipoprotein metabolism. Mol. Cell. Endocrinol. 2019, 498, 110547. [CrossRef] [PubMed] 
43. Fisher, E.A.; Zhou, M.; Mitchell, D.M.; Wu, X.; Omura, S.; Wang, H.; Goldberg, A.L.; Ginsberg, H.N. The degradation of apolipoprotein B100 is mediated by the ubiquitin-proteasome pathway and involves heat shock protein 70. J. Biol. Chem. 1997, 272, 20427-20434. [CrossRef] [PubMed]

44. Fisher, E.A.; Pan, M.; Chen, X.; Wu, X.; Wang, H.; Jamil, H.; Sparks, J.D.; Williams, K.J. The triple threat to nascent apolipoprotein B. Evidence for multiple, distinct degradative pathways. J. Biol. Chem. 2001, 276, 27855-27863. [CrossRef] [PubMed]

45. Kulinski, A.; Rustaeus, S.; Vance, J.E. Microsomal triacylglycerol transfer protein is required for lumenal accretion of triacylglycerol not associated with ApoB, as well as for ApoB lipidation. J. Biol. Chem. 2002, 277, 31516-31525. [CrossRef]

46. Wetterau, J.R.; Combs, K.A.; Spinner, S.N.; Joiner, B.J. Protein disulfide isomerase is a component of the microsomal triglyceride transfer protein complex. J. Biol. Chem. 1990, 265, 9800-9807. [CrossRef]

47. Innerarity, T.L.; Borén, J.; Yamanaka, S.; Olofsson, S.O. Biosynthesis of apolipoprotein B48-containing lipoproteins. Regulation by novel post-transcriptional mechanisms. J. Biol. Chem. 1996, 271, 2353-2356. [CrossRef]

48. Brodsky, J.L.; Gusarova, V.; Fisher, E.A. Vesicular trafficking of hepatic apolipoprotein B100 and its maturation to very low-density lipoprotein particles; studies from cells and cellfree systems. Trends Cardiovasc. Med. 2004, 14, 127-132. [CrossRef]

49. Sundaram, M.; Yao, Z. Recent progress in understanding protein and lipid factors affecting hepatic VLDL assembly and secretion. Nutr. Metab. 2010, 7, 35. [CrossRef]

50. Olofsson, S.O.; Wiklund, O.; Borén, J. Apolipoproteins A-I and B: Biosynthesis, role in the development of atherosclerosis and targets for intervention against cardiovascular disease. Vasc. Health Risk Manag. 2007, 3, 491-502.

51. Tiwari, S.; Siddiqi, S.A. Intracellular trafficking and secretion of VLDL. Arterioscler. Thromb. Vasc. Biol. 2012, 32, 1079-1086. [CrossRef]

52. Aneni, E.C.; Osondu, C.U.; De La Cruz, J.; Martin, S.S.; Blaha, M.J.; Younus, A.; Feldman, T.; Agatston, A.S.; Veledar, E.; Nasir, K. Lipoprotein Sub-Fractions by Ion-Mobility Analysis and Its Association with Subclinical Coronary Atherosclerosis in High-Risk Individuals. J. Atheroscler. Thromb. 2019, 26, 50-63. [CrossRef] [PubMed]

53. Mittendorfer, B.; Yoshino, M.; Patterson, B.W.; Klein, S. VLDL Triglyceride Kinetics in Lean, Overweight, and Obese Men and Women. J. Clin. Endocrinol. Metab. 2016, 101, 4151-4160. [CrossRef] [PubMed]

54. Welsh, J.A.; Sharma, A.; Abramson, J.L.; Vaccarino, V.; Gillespie, C.; Vos, M.B. Caloric sweetener consumption and dyslipidemia among US adults. J. Am. Med. Assoc. 2010, 303, 1490-1497. [CrossRef] [PubMed]

55. Wojczynski, M.K.; Glasser, S.P.; Oberman, A.; Kabagambe, E.K.; Hopkins, P.N.; Tsai, M.Y.; Straka, R.J.; Ordovas, J.M.; Arnett, D.K. High-fat meal effect on LDL, HDL, and VLDL particle size and number in the Genetics of Lipid-Lowering drugs and diet network (GOLDN): An interventional study. Lipids Health Dis. 2011, 10, 181. [CrossRef] [PubMed]

56. Adiels, M.; Mardinoglu, A.; Taskinen, M.R.; Borén, J. Kinetic Studies to Elucidate Impaired Metabolism of Triglyceride-rich Lipoproteins in Humans. Front. Physiol. 2015, 6, 342. [CrossRef] [PubMed]

57. Law, A.; Scott, J. A cross-species comparison of the apolipoprotein B domain that binds to the LDL receptor. J. Lipid Res. 1990, 31, 1109-1120. [CrossRef]

58. Brown, M.S.; Goldstein, J.L. Regulation of the activity of the low density lipoprotein receptor in human fibroblasts. Cell 1975, 6 , 307-316. [CrossRef]

59. Brunelli, R.; Greco, G.; Barteri, M.; Krasnowska, E.K.; Mei, G.; Natella, F.; Pala, A.; Rotella, S.; Ursini, F.; Zichella, L.; et al. One site on the apoB-100 specifically binds 17-beta-estradiol and regulates the overall structure of LDL. FASEB J. 2003, 17, 2127-2129. [CrossRef]

60. Hevonoja, T.; Pentikäinen, M.O.; Hyvönen, M.T.; Kovanen, P.T.; Ala-Korpela, M. Structure of low density lipoprotein (LDL) particles: Basis for understanding molecular changes in modified LDL. Biochim. Biophys. Acta 2000, 1488, 189-210. [CrossRef]

61. Bruikman, C.S.; Hovingh, G.K.; Kastelein, J.J. Molecular basis of familial hypercholesterolemia. Curr. Opin. Cardiol. 2017, 32, 262-266. [CrossRef]

62. Reiss, A.B.; Shah, N.; Muhieddine, D.; Zhen, J.; Yudkevich, J.; Kasselman, L.J.; DeLeon, J. PCSK9 in cholesterol metabolism: From bench to bedside. Clin. Sci. 2018, 132, 1135-1153. [CrossRef] [PubMed]

63. Brown, M.S.; Goldstein, J.L. A receptor-mediated pathway for cholesterol homeostasis. Science 1986, 232, 34-47. [CrossRef] [PubMed]

64. Klein-Szanto, A.J.P.; Bassi, D.E. Keep recycling going: New approaches to reduce LDL-C. Biochem. Pharmacol. 2019, 164, 336-341. [CrossRef] [PubMed]

65. Langer, T.; Strober, W.; Levy, R.I. The Metabolism of Low Density Lipoprotein in Familial Type II Hyperlipoproteinemia. J. Clin. Investig. 1972, 51, 1528-1536. [CrossRef] [PubMed]

66. Borén, J.; Olin, K.; Lee, I.; Chait, A.; Wight, T.N.; Innerarity, T.L. Identification of the principal proteoglycan-binding site in LDL. A single-point mutation in apo-B100 severely affects proteoglycan interaction without affecting LDL receptor binding. J. Clin. Investig. 1998, 101, 2658-2664. [CrossRef] [PubMed]

67. Gustafsson, M.; Borén, J. Mechanism of lipoprotein retention by the extracellular matrix. Curr. Opin. Lipidol. 2004, 15, 505-514. [CrossRef]

68. Olsson, U.; Camejo, G.; Hurt-Camej, E. Possible functional interactions of apolipoprotein B-100 segments that associate with cell proteoglycans and the apoB/E receptor. Arterioscler. Thromb. Vasc. Biol. 1997, 17, 149-155. [CrossRef]

69. Hurt-Camejo, E.; Camejo, G. ApoB-100 Lipoprotein Complex Formation with Intima Proteoglycans as a Cause of Atherosclerosis and Its Possible Ex Vivo Evaluation as a Disease Biomarker. J. Cardiovasc. Dev. Dis. 2018, 5, 36. [CrossRef] 
70. Borèn, J.; Lee, I.; Zhu, W. Identification of the low density lipoprotein receptor-binding site in apolipoprotein B100 and the modulation of its binding activity by the carboxyl terminus in familial defective apoB100. J. Clin. Investig. 1998, 101, 1084-1093. [CrossRef]

71. Oörni, K.; Pentikäinen, M.O.; Ala-Korpela, M.; Kovanen, P.T. Aggregation, fusion, and vesicle formation of modified low density lipoprotein particles: Molecular mechanisms and effects on matrix interactions. J. Lipid Res. 2000, 41, 1703-1714. [CrossRef]

72. Skålén, K.; Gustafsson, M.; Rydberg, E.K.; Hultén, L.M.; Wiklund, O.; Innerarity, T.L.; Borén, J. Subendothelial retention of atherogenic lipoproteins in early atherosclerosis. Nature 2002, 417, 750-754. [CrossRef]

73. Lu, M.; Gursky, O. Aggregation and fusion of low-density lipoproteins in vivo and in vitro. Biomol. Concepts 2013, 4, 501-518. [CrossRef]

74. Cooper, A.D. Hepatic uptake of chylomicron remnants. J. Lipid Res. 1997, 38, 2173-2192. [CrossRef]

75. Goldberg, I.J.; Wagner, W.D.; Pang, L.; Paka, L.; Curtiss, L.K.; DeLozier, J.A.; Shelness, G.S.; Young, C.S.; Pillarisetti, S. The NH2-terminal Region of Apolipoprotein B Is Sufficient for Lipoprotein Association with Glycosaminoglycans. J. Biol. Chem. 1998, 273, 35355-35361. [CrossRef] [PubMed]

76. Ebara, T.; Conde, K.; Kako, Y.; Liu, Y.; Xu, Y.; Ramakrishnan, R.; Goldberg, I.J.; Shachter, N.S. Delayed catabolism of apoB-48 lipoproteins due to decreased heparan sulfate proteoglycan production in diabetic mice. J. Clin. Investig. 2000, 105, 1807-1818. [CrossRef] [PubMed]

77. Vinagre, C.G.; Freitas, F.R.; de Mesquita, C.H.; Vinagre, J.C.; Mariani, A.C.; Kalil-Filho, R.; Maranhão, R.C. Removal of Chylomicron Remnants from the Bloodstream is Delayed in Aged Subjects. Aging Dis. 2018, 9, 748-754. [CrossRef] [PubMed]

78. Grundy, S.M.; Stone, N.J.; Bailey, A.L.; Beam, C.; Birtcher, K.K.; Blumenthal, R.S.; Braun, L.T.; de Ferranti, S.; Faiella-Tommasino, J.; Forman, D.E.; et al. 2018 AHA/ACC/AACVPR/AAPA/ABC/ACPM/ADA/AGS/APhA/ASPC/NLA/PCNA Guideline on the Management of Blood Cholesterol: A Report of the American College of Cardiology/American Heart Association Task Force on Clinical Practice Guidelines. Circulation 2019, 139, e1082-e1143. [PubMed]

79. Stone, N.J.; Robinson, J.G.; Lichtenstein, A.H.; Bairey Merz, C.N.; Blum, C.B.; Eckel, R.H.; Goldberg, A.C.; Gordon, D.; Levy, D.; Lloyd-Jones, D.M.; et al. American College of Cardiology/American Heart Association Task Force on Practice Guidelines. 2013 ACC / AHA guideline on the treatment of blood cholesterol to reduce atherosclerotic cardiovascular risk in adults: A report of the American College of Cardiology / American Heart Association Task Force on Practice Guidelines. J. Am. Coll. Cardiol. 2014, 63, 2889-2934. [PubMed]

80. Friedewald, W.T.; Levy, R.I.; Fredrickson, D.S. Estimation of the concentration of low-density lipoprotein cholesterol in plasma, without use of the preparative ultracentrifuge. Clin. Chem. 1972, 18, 499-502. [CrossRef] [PubMed]

81. Rifai, N.; Warnick, G.R.; McNamara, J.R. Measurement of low-density-lipoprotein cholesterol in serum: A status report. Clin. Chem. 1992, 38, 150-160. [CrossRef] [PubMed]

82. Hirany, S.; Li, D.; Jialal, I. A more valid measurement of low-density lipoprotein cholesterol in diabetic patients. Am. J. Med. 1997, 102, 48-53. [CrossRef]

83. Scharnagl, H.; Nauck, M.; Wieland, H.; März, W. The friedewald formula underestimates LDL cholesterol at low concentrations. Clin. Chem. Lab. Med. 2001, 39, 426-431. [CrossRef] [PubMed]

84. Sawle, A.; Higgins, M.K.; Olivant, M.P.; Higgins, J.A. A rapid single-step centrifugation method for determination of HDL, LDL, and VLDL cholesterol, and TG, and identification of predominant LDL subclass. J. Lipid Res. 2002, 43, 335-343. [CrossRef]

85. Rahman, F.; Blumenthal, R.S.; Jones, S.R. Fasting or Non-fasting Lipids for Atherosclerotic Cardiovascular Disease Risk Assessment and Treatment? Curr. Atheroscler. Rep. 2018, 20, 14. [CrossRef]

86. Ridker, P.M. LDL cholesterol: Controversies and future therapeutic directions. Lancet 2014, 384, 607-617. [CrossRef]

87. Silverman, M.G.; Ference, B.A.; Im, K.; Wiviott, S.D.; Giugliano, R.P.; Grundy, S.M.; Braunwald, E.; Sabatine, M.S. Association between lowering LDL-C and cardiovascular risk reduction among different therapeutic interventions: A systematic review and meta- analysis. J. Am. Med. Assoc. 2016, 316, 1289-1297. [CrossRef] [PubMed]

88. Boekholdt, S.M.; Hovingh, G.K.; Mora, S.; Arsenault, B.J.; Amarenco, P.; Pedersen, T.R.; LaRosa, J.C.; Waters, D.D.; DeMicco, D.A.; Simes, R.J.; et al. Very low levels of atherogenic lipoproteins and the risk for cardiovascular events: A meta-analysis of statin trials. J. Am. Coll. Cardiol. 2014, 64, 485-494. [CrossRef]

89. Cholesterol Treatment Trialists' (CTT) Collaboration; Fulcher, J.; O'Connell, R.; Voysey, M.; Emberson, J.; Blackwell, L.; Mihaylova, B.; Simes, J.; Collins, R.; Kirby, A.; et al. Efficacy and safety of LDL-lowering therapy among men and women: Meta-analysis of individual data from 174,000 participants in 27 randomised trials. Lancet 2015, 385, 1397-1405.

90. Kilgore, M.; Muntner, P.; Woolley, J.M.; Sharma, P.; Bittner, V.; Rosenson, R.S. Discordance between high non-HDL cholesterol and high LDL-cholesterol among US adults. J. Clin. Lipidol. 2014, 8, 86-93. [CrossRef]

91. Diffenderfer, M.R.; Schaefer, E.J. The composition and metabolism of large and small LDL. Curr. Opin. Lipidol. 2014, 25, 221-226. [CrossRef]

92. Contois, J.H.; McConnell, J.P.; Sethi, A.A.; Csako, G.; Devaraj, S.; Hoefner, D.M.; Warnick, G.R.; AACC Lipoproteins and Vascular Diseases Division Working Group on Best Practices. Apolipoprotein B and cardiovascular disease risk: Position statement from the AACC Lipoproteins and Vascular Diseases Division Working Group on Best Practices. Clin. Chem. 2009, 55, 407-419. [CrossRef]

93. Otvos, J.D. Measurement of triglyceride-rich lipoproteins by nuclear magnetic resonance spectroscopy. Clin. Cardiol. 1999, 22, II21-II27. [CrossRef] 
94. Goff, D.C., Jr.; Lloyd-Jones, D.M.; Bennett, G. 2013 ACC/AHA guideline on the assessment of cardiovascular risk: A report of the American College of Cardiology/American Heart Association Task Force on Practice Guidelines. Circulation 2014, 129, S49-S73. [CrossRef]

95. Preiss, D.; Kristensen, S.L. The New Pooled Cohort Equations Risk Calculator. Can. J. Cardiol. 2015, 31, 613-619. [CrossRef] [PubMed]

96. Hwang, Y.C.; Ahn, H.Y.; Han, K.H.; Park, S.W.; Park, C.Y. Prediction of future cardiovascular disease with an equation to estimate apolipoprotein B in patients with high cardiovascular risk: An analysis from the TNT and IDEAL study. Lipids Health Dis. 2017, 16, 158. [CrossRef] [PubMed]

97. Weitgasser, R.; Ratzinger, M.; Hemetsberger, M.; Siostrzonek, P. LDL-cholesterol and cardiovascular events: The lower the better? Wiener Medizinische Wochenschrift 2018, 168, 108. [CrossRef] [PubMed]

98. Ivanova, E.A.; Myasoedova, V.A.; Melnichenko, A.A.; Grechko, A.V.; Orekhov, A.N. Small Dense Low-Density Lipoprotein as Biomarker for Atherosclerotic Diseases. Oxid. Med. Cell. Longev. 2017, 2017, e1273042. [CrossRef]

99. Averna, M.; Stroes, E. Lipid alterations beyond LDL expert working group. How to assess and manage cardiovascular risk associated with lipid alterations beyond LDL. Atheroscler. Suppl. 2017, 26, 16-24. [CrossRef]

100. Virani, S.S. Non-HDL cholesterol as a metric of good quality of care: Opportunities and challenges. Tex. Heart Inst. J. 2011, 38, 160-162.

101. Cannon, C.P.; Braunwald, E.; McCabe, C.H.; Rader, D.J.; Rouleau, J.L.; Belder, R.; Joyal, S.V.; Hill, K.A.; Pfeffer, M.A.; Skene, A.M Pravastatin or Atorvastatin Evaluation and Infection Therapy-Thrombolysis in Myocardial Infarction 22 Investigators. Intensive versus moderate lipid lowering with statins after acute coronary syndromes. N. Engl. J. Med. 2004, 350, 1495-1504. [CrossRef]

102. Bachorik, P.S.; Ross, J.W. National Cholesterol Education Program recommendations for measurement of low-density lipoprotein cholesterol: Executive summary. The National Cholesterol Education Program Working Group on Lipoprotein Measurement. Clin. Chem. 1995, 41, 1414-1420. [CrossRef]

103. Davidson, M.H.; Maki, K.C.; Pearson, T.A.; Pasternak, R.C.; Deedwania, P.C.; McKenney, J.M.; Fonarow, G.C.; Maron, D.J.; Ansell, B.J.; Clark, L.T.; et al. Results of the National Cholesterol Education (NCEP) Program Evaluation Project Utilizing Novel E-Technology (NEPTUNE) II survey and implications for treatment under the recent NCEP Writing Group recommendations. Am. J. Cardiol. 2005, 96, 556-563. [CrossRef]

104. Khanji, M.Y.; Bicalho, V.V.; van Waardhuizen, C.N.; Ferket, B.S.; Petersen, S.E.; Hunink, M.G. Cardiovascular risk assessment: A systematic review of guidelines. Ann. Intern. Med. 2016, 165, 713-722. [CrossRef]

105. Soran, H.; Ho, J.H.; Adam, S.; Durrington, P.N. Non-HDL cholesterol should not generally replace LDL cholesterol in the management of hyperlipidaemia. Curr. Opin. Lipidol. 2019, 30, 263-272. [CrossRef]

106. Hermans, M.P.; Ahn, S.A.; Rousseau, M.F. Novel unbiased equations to calculate triglyceride rich lipoprotein cholesterol from routine non-fasting lipids. Cardiovasc. Diabetol. 2014, 13, 56. [CrossRef] [PubMed]

107. Grundy, S.M.; Stone, N.J. Elevated apolipoprotein B as a risk-enhancing factor in 2018 cholesterol guidelines. J. Clin. Lipidol. 2019, 13, 356-359. [CrossRef] [PubMed]

108. Sniderman, A.D.; Williams, K.; Contois, J.H.; Monroe, H.M.; McQueen, M.J.; de Graaf, J.; Furberg, C.D. A meta-analysis of low-density lipoprotein cholesterol, non-high-density lipoprotein cholesterol, and apolipoprotein B as markers of cardiovascular risk. Circ. Cardiovasc. Qual. Outcomes 2011, 4, 337-345. [CrossRef] [PubMed]

109. Sandhu, P.K.; Musaad, S.M.; Remaley, A.T.; Buehler, S.S.; Strider, S.; Derzon, J.H.; Vesper, H.W.; Ranne, A.; Shaw, C.S.; Christenson, R.H. Lipoprotein Biomarkers and Risk of Cardiovascular Disease: A Laboratory Medicine Best Practices (LMBP) Systematic Review. J. Appl. Lab. Med. 2016, 1, 214-229. [CrossRef]

110. Pedro-Botet, J.; Mantilla-Morató, T.; Díaz-Rodríguez, Á.; Brea-Hernando, Á.; González-Santos, P.; Hernández-Mijares, A.; Pintó, X.; Millán Núñez-Cortés, J. El papel de la dislipemia aterogénica en las guías de práctica clínica [The role of atherogenic dyslipidaemia in clinical practice guidelines]. Clin. Investig. Arterioscler. 2016, 28, 65-70.

111. de Nijs, T.; Sniderman, A.; de Graaf, J. Apo B versus non-HDL-cholesterol: Diagnosis and cardiovascular risk assessment. Crit. Rev. Clin. Laboratory Sci. 2013, 50, 163-171. [CrossRef] [PubMed]

112. Mach, F.; Baigent, C.; Catapano, A.L.; Koskinas, K.C.; Casula, M.; Badimon, L.; Chapman, M.J.; De Backer, G.G.; Delgado, V.; Ference, B.A.; et al. ESC Scientific Document Group. 2019 ESC/EAS Guidelines for the management of dyslipidaemias: Lipid modification to reduce cardiovascular risk. Eur. Heart J. 2020, 41, 111-188. [CrossRef]

113. Barter, P.J.; Ballantyne, C.M.; Carmena, R.; Castro Cabezas, M.; Chapman, M.J.; Couture, P.; de Graaf, J.; Durrington, P.N.; Faergeman, O.; Frohlich, J.; et al. Apo B versus cholesterol in estimating cardiovascular risk and in guiding therapy: Report of the thirty-person/ten-country panel. J. Int. Med. 2006, 259, 247-258. [CrossRef] [PubMed]

114. Holewijn, S.; den Heijer, M.; van Tits, L.J.; Swinkels, D.W.; Stalenhoef, A.F.; de Graaf, J. Apolipoprotein B, non-HDL cholesterol and LDL cholesterol for identifying individuals at increased cardiovascular risk. J. Intern. Med. 2010, 268, 567-577. [CrossRef]

115. Carr, S.S.; Hooper, A.J.; Sullivan, D.R.; Burnett, J.R. Non-HDL-cholesterol and apolipoprotein B compared with LDL-cholesterol in atherosclerotic cardiovascular disease risk assessment. Pathology 2019, 51, 148-154. [CrossRef]

116. Langlois, M.R.; Sniderman, A.D. Non-HDL Cholesterol or apoB: Which to Prefer as a Target for the Prevention of Atherosclerotic Cardiovascular Disease? Curr. Cardiol. Rep. 2020, 22, 67. [CrossRef] [PubMed]

117. Meeusen, J.W.; Donato, L.J.; Jaffe, A.S. Should apolipoprotein B replace LDL cholesterol as therapeutic targets are lowered? Curr. Opin. Lipidol. 2016, 27, 359-366. [CrossRef] [PubMed] 
118. Sampson, U.K.; Fazio, S.; Linton, M.F. Residual cardiovascular risk despite optimal LDL cholesterol reduction with statins: The evidence, etiology, and therapeutic challenges. Curr. Atheroscler. Rep. 2014, 14, 1-10. [CrossRef]

119. Lloyd-Jones, D.; Adams, R.J.; Brown, T.M.; Carnethon, M.; Dai, S.; De Simone, G.; Ferguson, T.B.; Ford, E.; Furie, K.; Gillespie, C.; et al. American Heart Association Statistics Committee and Stroke Statistics Subcommittee. Executive summary: Heart disease and stroke statistics-2010 update: A report from the American Heart Association. Circulation 2010, 121, 948-954.

120. Sniderman, A.D.; Pencina, M.; Thanassoulis, G. ApoB: The power of physiology to transform the prevention of cardiovascular disease. Circ. Res. 2019, 124, 1425-1427. [CrossRef]

121. Cantey, E.P.; Wilkins, J.T. Discordance between lipoprotein particle number and cholesterol content: An update. Curr. Opin. Endocrinol. Diabetes Obes. 2018, 25, 130-136. [CrossRef]

122. Sniderman, A.D.; Vu, H.; Cianflone, K. The effect of moderate hypertriglyceridemia on the relation of plasma total and LDL apoB levels. Atherosclerosis 1991, 89, 109-116. [CrossRef]

123. Durrington, P.N.; Bolton, C.N.; Hartog, H. Serum and lipoprotein apolipoprotein B levels in normal subjects and patients with hyperlipoproteinemia. Clin. Chim. Acta 1978, 82, 151-160. [CrossRef]

124. Benn, M.; Nordestgaard, B.G.; Jensen, G.B.; Tybjaerg-Hansen, A. Improving prediction of ischemic cardiovascular disease in the general population using apolipoprotein B: The Copenhagen City Heart Study. Arterioscler. Thromb. Vasc. Biol. 2007, 27, 661-670. [CrossRef] [PubMed]

125. Pischon, T.; Girman, C.J.; Sacks, F.M.; Rifai, N.; Stampfer, M.J.; Rimm, E.B. Non-high-density lipoprotein cholesterol and apolipoprotein B in the prediction of coronary heart disease in men. Circulation 2005, 112, 3375-3383. [CrossRef]

126. Walldius, G.; Jungner, I.; Holme, I.; Aastveit, A.H.; Kolar, W.; Steiner, E. High apolipoprotein B, low apolipoprotein A-I, and improvement in the prediction of fatal myocardial infarction (AMORIS study): A prospective study. Lancet 2001, 358, 2026-2033. [CrossRef]

127. Ohwada, T.; Sakamoto, T.; Kanno, Y.; Yokokawa, S.; Amami, K.; Nakazato, K.; Takeishi, Y.; Watanabe, K. Apolipoprotein B correlates with intra-plaque necrotic core volume in stable coronary artery disease. PLoS ONE 2019, 14, e0212539. [CrossRef]

128. Krauss, R.M. Atherogenicity of triglyceride-rich lipoproteins. Am. J. Cardiol. 1998, 81, 13B-17B. [CrossRef]

129. Graziani, M.S.; Zanolla, L.; Righetti, G.; Marchetti, C.; Mocarelli, P.; Marcovina, S.M. Plasma apolipoproteins A-I and B in survivors of myocardial infarction and in a control group. Clin. Chem. 1998, 44, 134-140. [CrossRef]

130. Westerveld, H.T.; van Lennep, J.E.; van Lennep, H.W.; Liem, A.H.; de Boo, J.A.; van der Schouw, Y.T.; Erkelens, D.W. Apolipoprotein B and coronary artery disease in women: A cross-sectional study in women undergoing their first coronary angiography. Arterioscler. Thromb. Vasc. Biol. 1998, 18, 1101-1107. [CrossRef]

131. Sniderman, A.D. Counterpoint: To (measure apo) B or not to (measure apo) B: A critique of modern medical decision-making. Clin. Chem. 1997, 43, 1310-1314. [CrossRef]

132. Sacks, F.M.; Alaupovic, P.; Moye, L.A.; Cole, T.G.; Sussex, B.; Stampfer, M.J.; Pfeffer, M.A.; Braunwald, E. VLDL, apolipoproteins B, CIII, and E, and risk of recurrent coronary events in the Cholesterol and Recurrent Events (CARE) trial. Circulation 2000, 102, 1886-1892. [CrossRef] [PubMed]

133. Sniderman, A.D.; de Graaf, J.; Thanassoulis, G.; Tremblay, A.J.; Martin, S.S.; Couture, P. The spectrum of type III hyperlipoproteinemia. J. Clin. Lipidol. 2018, 12, 1383-1389. [CrossRef] [PubMed]

134. Cao, J.; Steffen, B.T.; Guan, W.; Remaley, A.T.; McConnell, J.P.; Palamalai, V.; Tsai, M.Y. A comparison of three apolipoprotein B methods and their associations with incident coronary heart disease risk over a 12-year follow-up period: The Multi-Ethnic Study of Atherosclerosis. J. Clin. Lipidol. 2018, 12, 300-304. [CrossRef]

135. Hermans, M.P.; Sacks, F.M.; Ahn, S.A.; Rousseau, M.F. Non-HDL-cholesterol as valid surrogate to apolipoprotein B100 measurement in diabetes: Discriminant Ratio and unbiased equivalence. Cardiovasc. Diabetol. 2011, 10, 20. [CrossRef]

136. Hwang, Y.C.; Ahn, H.Y.; Lee, W.J.; Park, C.Y.; Park, S.W. An equation to estimate the concentration of serum apolipoprotein B. PLoS ONE 2012, 7, e51607. [CrossRef]

137. de Vries, M.A.; van Santen, S.S.; Klop, B.; van der Meulen, N.; van Vliet, M.; van de Geijn, G.M.; van der Zwan-van Beek, E.M.; Birnie, E.; Liem, A.H.; de Herder, W.W.; et al. Erythrocyte-bound apolipoprotein B in atherosclerosis and mortality. Eur. J. Clin. Investig. 2017, 47, 289-296. [CrossRef] [PubMed]

138. Walldius, G.; Jungner, I. The apoB/apoA-I ratio: A strong, new risk factor for cardiovascular disease and a target for lipid-lowering therapy-a review of the evidence. J. Intern. Med. 2006, 259, 493-519. [CrossRef]

139. Bachorik, P.S.; Lovejoy, K.L.; Carroll, M.D.; Johnson, C.L. Apolipoprotein B and AI distributions in the United States, 1988-1991: Results of the National Health and Nutrition Examination Survey III (NHANES III). Clin. Chem. 1997, 43, 2364-2378. [CrossRef]

140. Barter, P.J.; Rye, K.A. The rationale for using apoA-I as a clinical marker of cardiovascular risk. J. Intern. Med. 2006, 239, 447-454. [CrossRef]

141. Walldius, G.; Jungner, I. Is there a better marker of cardiovascular risk than LDL cholesterol? Apolipoproteins B and A-I-new risk factors and targets for therapy. Nutr. Metab. Cardiovasc. Dis. 2007, 17, 565-571. [CrossRef]

142. Holme, I.; Aastveit, A.H.; Jungner, I.; Walldius, G. Relationships between lipoprotein components and risk of myocardial infarction: Age, gender and short versus longer follow-up periods in the Apolipoprotein Mortality Risk Study (AMORIS). J. Intern. Med. 2008, 264, 30-38. [CrossRef] 
143. Yusuf, S.; Hawken, S.; Ounpuu, S.; Dans, T.; Avezum, A.; Lanas, F.; McQueen, M.; Budaj, A.; Pais, P.; Varigos, J. Effect of potentially modifiable risk factors associated with myocardial infarction in 52 countries (the INTERHEART study): Case-control study. Lancet 2004, 264, 937-952. [CrossRef]

144. Tian, M.; Li, R.; Shan, Z.; Wang, D.W.; Jiang, J.; Cui, G. Comparison of apolipoprotein B/A1 ratio, Framingham risk score and TC/HDL-c for predicting clinical outcomes in patients undergoing percutaneous coronary intervention. Lipids Health Dis. 2019, 18, 202. [CrossRef]

145. Ivert, T.; Malmström, H.; Hammar, N.; Carlsson, A.C.; Wändell, P.E.; Holzmann, M.J.; Jungner, I.; Ärnlöv, J.; Walldius, G. Cardiovascular events in patients under age fifty with early findings of elevated lipid and glucose levels-The AMORIS study. PLoS ONE 2018, 13, e0201972. [CrossRef] [PubMed]

146. Sierra-Johnson, J.; Fisher, R.M.; Romero-Corral, A.; Somers, V.K.; Lopez-Jimenez, F.; Ohrvik, J.; Walldius, G.; Hellenius, M.L.; Hamsten, A. Concentration of apolipoprotein B is comparable with the apolipoprotein B/apolipoprotein A-I ratio and better than routine clinical lipid measurements in predicting coronary heart disease mortality: Findings from a multi-ethnic US population. Eur. Heart J. 2009, 30, 710-717. [CrossRef] [PubMed]

147. Sierra-Johnson, J.; Romero-Corral, A.; Somers, V.K.; Lopez-Jimenez, F.; Walldius, G.; Hamsten, A.; Hellenius, M.L.; Fisher, R.M. ApoB/apoA-I ratio: An independent predictor of insulin resistance in US non-diabetic subjects. Eur. Heart J. 2007, 28, 2637-2643. [CrossRef]

148. Martin, S.S.; Qasim, A.N.; Mehta, N.N.; Wolfe, M.; Terembula, K.; Schwartz, S.; Iqbal, N.; Schutta, M.; Bagheri, R.; Reilly, M.P. Apolipoprotein B but not LDL cholesterol is associated with coronary artery calcification in type 2 diabetic whites. Diabetes 2009, 58, 1887-1892. [CrossRef]

149. Chen, Y.; Shang, D.; Shao, J.; Dai, S.; Ge, X.; Hao, C.; Zhu, T. Prognostic significance of carotid plaque presence in peritoneal dialysis patients and its association with the apolipoprotein B/apolipoprotein A1 ratio. Nephrology 2020, 25, 919-928. [CrossRef]

150. Karasek, D.; Vaverkova, H.; Cibickova, L.; Gajdova, J.; Kubickova, V. Apolipoprotein B vs non-high-density lipoprotein cholesterol: Association with endothelial hemostatic markers and carotid intima-media thickness. J. Clin. Lipidol. 2017, 11, 442-449. [CrossRef] [PubMed]

151. McClelland, R.L.; Jorgensen, N.W.; Budoff, M.; Blaha, M.J.; Post, W.S.; Kronmal, R.A.; Bild, D.E.; Shea, S.; Liu, K.; Watson, K.E.; et al. 10-year coronary heart disease risk prediction using coronary artery calcium and traditional risk factors: Derivation in the multi-ethnic study of atherosclerosis with validation in the Heinz Nixdorf recall study and the Dallas Heart Study. J. Am. Coll. Cardiol. 2015, 66, 1643-1653. [CrossRef]

152. Sequí-Domínguez, I.; Cavero-Redondo, I.; Álvarez-Bueno, C.; Pozuelo-Carrascosa, D.P.; Nuñez de Arenas-Arroyo, S.; MartínezVizcaíno, V. Accuracy of Pulse Wave Velocity Predicting Cardiovascular and All-Cause Mortality. A Systematic Review and Meta-Analysis. J. Clin. Med. 2020, 9, 2080. [CrossRef]

153. Jagannathan, R.; Patel, S.A.; Ali, M.K.; Narayan, K. Global updates on cardiovascular disease mortality trends and attribution of traditional risk factors. Curr. Diab. Rep. 2019, 19, 44. [CrossRef]

154. Dieter, B.P.; Tuttle, K.R. Dietary strategies for cardiovascular health. Trends Cardiovasc. Med. 2017, 27, 295-313. [CrossRef] [PubMed]

155. Isakadze, N.; Mehta, P.K.; Law, K.; Dolan, M.; Lundberg, G.P. Addressing the gap in physician preparedness to assess cardiovascular risk in women: A comprehensive approach to cardiovascular risk assessment in women. Curr. Treat. Options Cardiovasc. Med. 2019, 21, 47. [CrossRef]

156. Cannon, C.P. Cardiovascular disease and modifiable cardiometabolic risk factors. Clin. Cornerstone 2007, 8, 11-28. [CrossRef]

157. D'Agostino, R.B., Sr.; Vasan, R.S.; Pencina, M.J.; Wolf, P.A.; Cobain, M.; Massaro, J.M.; Kannel, W.B. General cardiovascular risk profile for use in primary care: The Framingham Heart Study. Circulation 2008, 117, 743-753. [CrossRef] [PubMed]

158. Wilson, P.W.; D'Agostino, R.B.; Levy, D.; Belanger, A.M.; Silbershatz, H.; Kannel, W.B. Prediction of coronary heart disease using risk factor categories. Circulation 1998, 97, 1837-1847. [CrossRef]

159. Williams, K.; Sniderman, A.D.; Sattar, N.; D’Agostino, R., Jr.; Wagenknecht, L.E.; Haffner, S.M. Comparison of the associations of apolipoprotein B and low-density lipoprotein cholesterol with other cardiovascular risk factors in the Insulin Resistance Atherosclerosis Study (IRAS). Circulation 2003, 108, 2312-2316. [CrossRef]

160. Rosenblit, P.D. Extreme Atherosclerotic Cardiovascular Disease (ASCVD) risk recognition. Curr. Diab. Rep. 2019, 19, 61. [CrossRef] [PubMed]

161. Enkhmaa, B.; Anuurad, E.; Zhang, W.; Berglund, L. Significant associations between lipoprotein(a) and corrected apolipoprotein B-100 levels in African-Americans. Atherosclerosis 2014, 235, 223-229. [CrossRef]

162. Tsimikas, S.; Clopton, P.; Brilakis, E.S.; Marcovina, S.M.; Khera, A.; Miller, E.R.; de Lemos, J.A.; Witztum, J.L. Relationship of oxidized phospholipids on apolipoprotein B-100 particles to race/ethnicity, apolipoprotein(a) isoform size, and cardiovascular risk factors: Results from the Dallas Heart Study. Circulation 2009, 119, 1711-1719. [CrossRef] [PubMed]

163. Matthan, N.R.; Jalbert, S.M.; Barrett, P.H.; Dolnikowski, G.G.; Schaefer, E.J.; Lichtenstein, A.H. Gender-specific differences in the kinetics of nonfasting TRL, IDL, and LDL apolipoprotein B-100 in men and premenopausal women. Arterioscler. Thromb. Vasc. Biol. 2008, 28, 1838-1843. [CrossRef] [PubMed]

164. Jungner, I.; Marcovina, S.M.; Walldius, G.; Holme, I.; Kolar, W.; Steiner, E. Apolipoprotein B and A-I values in 147576 Swedish males and females, standardized according to the World Health Organization-International Federation of Clinical Chemistry First International Reference Materials. Clin. Chem. 1998, 44, 1641-1649. [CrossRef] [PubMed] 
165. Matthan, N.R.; Jalbert, S.M.; Lamon-Fava, S.; Dolnikowski, G.G.; Welty, F.K.; Barrett, H.R.; Schaefer, E.J.; Lichtenstein, A.H. TRL, IDL, and LDL apolipoprotein B-100 and HDL apolipoprotein A-I kinetics as a function of age and menopausal status. Arterioscler. Thromb. Vasc. Biol. 2005, 25, 1691-1696. [CrossRef] [PubMed]

166. Dansinger, M.L.; Williams, P.T.; Superko, H.R.; Schaefer, E.J. Effects of weight change on apolipoprotein B-containing emerging atherosclerotic cardiovascular disease (ASCVD) risk factors. Lipids Health Dis. 2019, 18, 154. [CrossRef] [PubMed]

167. Sundfør, T.M.; Svendsen, M.; Heggen, E.; Dushanov, S.; Klemsdal, T.O.; Tonstad, S. BMI modifies the effect of dietary fat on atherogenic lipids: A randomized clinical trial. Am. J. Clin. Nutr. 2019, 110, 832-841. [CrossRef]

168. Lamantia, V.; Sniderman, A.; Faraj, M. Nutritional management of hyperapoB. Nutr. Res. Rev. 2016, 29, 202-233. [CrossRef]

169. Wilkins, J.T.; Li, R.C.; Sniderman, A.; Chan, C.; Lloyd-Jones, D.M. Discordance between apolipoprotein B and LDL-cholesterol in young adults predicts coronary artery calcification. J. Am. Coll. Cardiol. 2016, 67, 193-201. [CrossRef]

170. Sniderman, A.D.; Islam, S.; McQueen, M.; Pencina, M.; Furberg, C.D.; Thanassoulis, G.; Yusuf, S. Age and cardiovascular risk attributable to apolipoprotein B, low-density lipoprotein cholesterol or non-high-density lipoprotein cholesterol. J. Am. Heart Assoc. 2016, 5, e003665. [CrossRef] [PubMed]

171. Varvel, S.A.; Dayspring, T.D.; Edmonds, Y.; Thiselton, D.L.; Ghaedi, L.; Voros, S.; McConnell, J.P.; Sasinowski, M.; Dall, T.; Warnick, G.R. Discordance between apolipoprotein B and low-density lipoprotein particle number is associated with insulin resistance in clinical practice. J. Clin. Lipidol. 2015, 9, 247-255. [CrossRef]

172. Paredes, S.; Fonseca, L.; Ribeiro, L.; Ramos, H.; Oliveira, J.C.; Palma, I. Novel and traditional lipid profiles in metabolic syndrome reveal a high atherogenicity. Sci. Rep. 2019, 9, 11792. [CrossRef]

173. Faraj, M.; Messier, L.; Bastard, J.P.; Tardif, A.; Godbout, A.; Prud'homme, D.; Rabasa-Lhoret, R. Apolipoprotein B: A predictor of inflammatory status in postmenopausal overweight and obese women. Diabetologia 2006, 49, 1637-1646. [CrossRef] [PubMed]

174. Hwang, Y.C.; Ahn, H.Y.; Park, S.W.; Park, C.Y. Apolipoprotein B and non-HDL cholesterol are more powerful predictors for incident type 2 diabetes than fasting glucose or glycated hemoglobin in subjects with normal glucose tolerance: A 3.3-year retrospective longitudinal study. Acta Diabetol. 2014, 51, 941-946. [CrossRef]

175. Cartier, L.J.; St-Coeur, S.; Robin, A.; Lagace, M.; Douville, P. Impact of the Martin/Hopkins modified equation for estimating LDL-C on lipid target attainment in a high risk patient population. Clin. Biochem. 2020, 76, 35-37. [CrossRef] [PubMed]

176. Blasco, M.; Ascaso, J.F. Control of the overall lipid profile. Clin. Investig. Arterioscler. 2019, 31, 34-41. [PubMed]

177. Lamantia, V.; Bissonnette, S.; Wassef, H.; Cyr, Y.; Baass, A.; Dufour, R.; Rabasa-Lhoret, R.; Faraj, M. ApoB-lipoproteins and dysfunctional white adipose tissue: Relation to risk factors for type 2 diabetes in humans. J. Clin. Lipidol. 2017, 11, 34-45. [CrossRef] [PubMed]

178. Ley, S.H.; Harris, S.B.; Connelly, P.W.; Mamakeesick, M.; Gittelsohn, J.; Wolever, T.M.; Hegele, R.A.; Zinman, B.; Hanley, A.J. Association of apolipoprotein B with incident type 2 diabetes in an aboriginal Canadian population. Clin. Chem. 2010, 56, 666-670. [CrossRef]

179. Salomaa, V.; Havulinna, A.; Saarela, O.; Zeller, T.; Jousilahti, P.; Jula, A.; Muenzel, T.; Aromaa, A.; Evans, A.; Kuulasmaa, K.; et al. Thirty-one novel biomarkers as predictors for clinically incident diabetes. PLoS ONE 2010, 5, e10100. [CrossRef] [PubMed]

180. Onat, A.; Can, G.; Hergenç, G.; Yazici, M.; Karabulut, A.; Albayrak, S. Serum apolipoprotein B predicts dyslipidemia, metabolic syndrome and, in women, hypertension and diabetes, independent of markers of central obesity and inflammation. Int. J. Obes. 2007, 31, 1119-1125. [CrossRef] [PubMed]

181. Mikhailidis, D.P.; Elisaf, M.; Rizzo, M.; Berneis, K.; Griffin, B.; Zambon, A.; Athyros, V.; de Graaf, J.; März, W.; Parhofer, K.G.; et al. "European panel on low density lipoprotein (LDL) subclasses": A statement on the pathophysiology, atherogenicity and clinical significance of LDL subclasses: Executive summary. Curr. Vasc. Pharmacol. 2011, 9, 531-532. [CrossRef] [PubMed]

182. Zhang, N.; Ren, F.G.; Guan, K.P. Predictive Value of Small Dense Low-Density Lipoprotein in Coronary Heart Disease in the Chinese Population. Clin. Lab. 2021, 67, 5. [CrossRef]

183. Berneis, K.K.; Krauss, R.M. Metabolic origins and clinical significance of LDL heterogeneity. J. Lipid Res. 2002, 43, 1363-1379. [CrossRef]

184. Packard, C.J.; Demant, T.; Stewart, J.P.; Bedford, D.; Caslake, M.J.; Schwertfeger, G.; Bedynek, A.; Shepherd, J.; Seidel, D. Apolipoprotein B metabolism and the distribution of VLDL and LDL subfractions. J. Lipid Res. 2000, 41, 305-318. [CrossRef]

185. Hayashi, T.; Hirano, T.; Shiobara, T.; Suguro, T.; Adachi, M. Small dense LDL concentration is closely associated with serum apolipoprotein B, comparisons of non-LDL cholesterol or LDL cholesterol. Rinsho Byori 2006, 54, 569-575. [PubMed]

186. Vekic, J.; Zeljkovic, A.; Jelic-Ivanovic, Z.; Spasojevic-Kalimanovska, V.; Bogavac-Stanojevic, N.; Memon, L.; Spasic, S. Small, dense LDL cholesterol and apolipoprotein B: Relationship with serum lipids and LDL size. Atherosclerosis 2009, 207, 496-501. [CrossRef] [PubMed]

187. Rizzo, M.; Spinas, G.A.; Cesur, M.; Ozbalkan, Z.; Rini, G.B.; Berneis, K. Atherogenic lipoprotein phenotype and LDL size and subclasses in drug-naïve patients with early rheumatoid arthritis. Atherosclerosis 2009, 207, 502-506. [CrossRef]

188. Olusi, S.O.; George, S. Prevalence of LDL atherogenic phenotype in patients with systemic lupus erythematosus. Vasc. Health Risk Manag. 2011, 7, 75-80. [CrossRef] [PubMed]

189. Rizvi, A.A.; Cuadra, S.; Nikolic, D.; Giglio, R.V.; Montalto, G.; Rizzo, M. Gestational diabetes and the metabolic syndrome: Can obesity and small, dense low density lipoproteins be key mediators of this association? Curr. Pharm. Biotechnol. 2014, 15, 38-46. [CrossRef] [PubMed] 
190. Rizzo, M.; Berneis, K.; Altinova, A.E.; Toruner, F.B.; Akturk, M.; Ayvaz, G.; Rini, G.B.; Spinas, G.A.; Arslan, M. Atherogenic lipoprotein phenotype and LDL size and subclasses in women with gestational diabetes. Diabet Med. 2008, 25, $1406-1411$. [CrossRef]

191. Hirano, T. Small Dense LDL Tied to Diabetic Retinopathy-Similarity to Atherosclerosis. J. Atheroscler. Thromb. 2021, in press. [CrossRef]

192. Chapman, M.J.; Orsoni, A.; Tan, R.; Mellett, N.A.; Nguyen, A.; Robillard, P.; Giral, P.; Thérond, P.; Meikle, P.J. LDL subclass lipidomics in atherogenic dyslipidemia: Effect of statin therapy on bioactive lipids and dense LDL. Lipid Res. 2020, 61, 911-932. [CrossRef] [PubMed]

193. Viktorinova, A.; Malickova, D.; Svitekova, K.; Choudhury, S.; Krizko, M. Low-density lipoprotein cholesterol-to-apolipoprotein B ratio as a potential indicator of LDL particle size and plasma atherogenicity in type 2 diabetes. Diabetes Res. Clin. Pract. 2021, 176, 108858. [CrossRef] [PubMed]

194. Hirano, T.; Kodera, R.; Hirashima, T.; Suzuki, N.; Aoki, E.; Hosoya, M.; Oshima, T.; Hayashi, T.; Koba, S.; Ohta, M.; et al. Metabolic Properties of Low density Lipoprotein (LDL) Triglycerides in Patients with Type 2 Diabetes, Comparison with Small Dense LDL-Cholesterol. J. Atheroscler. Thromb. 2021, in press. [CrossRef] [PubMed]

195. Zheng, C.; Khoo, C.; Furtado, J.; Sacks, F.M. Apolipoprotein C-III and the metabolic basis for hypertriglyceridemia and the dense low-density lipoprotein phenotype. Circulation 2010, 121, 1722-1734. [CrossRef] [PubMed]

196. Rizzo, M.; Pernice, V.; Frasheri, A.; Berneis, K. Atherogenic lipoprotein phenotype and LDL size and subclasses in patients with peripheral arterial disease. Atherosclerosis 2008, 197, 237-241. [CrossRef]

197. Rizzo, M.; Berneis, K. Who needs to care about small, dense low-density lipoproteins? Int. J. Clin. Pract. 2007, 61, 1949-1956. [CrossRef]

198. Kou, M.; Ding, N.; Ballew, S.H.; Salameh, M.J.; Martin, S.S.; Selvin, E.; Heiss, G.; Ballantyne, C.M.; Matsushita, K.; Hoogeveen, R.C. Conventional and Novel Lipid Measures and Risk of Peripheral Artery Disease. Arterioscler. Thromb. Vasc. Biol. 2021, 41, 1229-1238. [CrossRef]

199. Sjögren, P.; Fredrikson, G.N.; Samnegard, A.; Ericsson, C.G.; Ohrvik, J.; Fisher, R.M.; Nilsson, J.; Hamsten, A. High plasma concentrations of autoantibodies against native peptide 210 of apoB-100 are related to less coronary atherosclerosis and lower risk of myocardial infarction. Eur. Heart J. 2008, 29, 2218-2226. [CrossRef]

200. Barter, P.J. CETP and atherosclerosis. Arterioscler. Thromb. Vasc. Biol. 2000, 20, 2029-2031. [CrossRef] [PubMed]

201. Barter, P.J.; Brewer, H.B., Jr.; Chapman, M.J.; Hennekens, C.H.; Rader, D.J.; Tall, A.R. Cholesteryl ester transfer protein: A novel target for raising HDL and inhibiting atherosclerosis. Arterioscler. Thromb. Vasc. Biol. 2003, 23, 160-167. [CrossRef] [PubMed]

202. Tall, A.R. Functions of cholesterol ester transfer protein and relationship to coronary artery disease risk. J. Clin. Lipidol. 2010, 4, 389-393. [CrossRef]

203. Ference, B.A.; Kastelein, J.; Ginsberg, H.N.; Chapman, M.J.; Nicholls, S.J.; Ray, K.K.; Packard, C.J.; Laufs, U.; Brook, R.D.; Oliver-Williams, C.; et al. Association of genetic variants related to CETP inhibitors and statins with lipoprotein levels and cardiovascular risk. J. Am. Med. Assoc. 2017, 318, 947-956. [CrossRef]

204. Nicholls, S.J.; Tuzcu, E.M.; Brennan, D.M.; Tardif, J.C.; Nissen, S.E. Cholesteryl ester transfer protein inhibition, high-density lipoprotein raising, and progression of coronary atherosclerosis: Insights from ILLUSTRATE (Investigation of Lipid Level Management Using Coronary Ultrasound to Assess Reduction of Atherosclerosis by CETP Inhibition and HDL Elevation). Circulation 2008, 118, 2506-2514.

205. Hegele, R.A. CETP inhibitors-a new inning? N. Engl. J. Med. 2017, 377, 1284-1285. [CrossRef]

206. Barter, P.J.; Caulfield, M.; Eriksson, M.; Grundy, S.M.; Kastelein, J.J.; Komajda, M.; Lopez-Sendon, J.; Mosca, L.; Tardif, J.C.; Waters, D.D.; et al. Illuminate Investigators. Effects of torcetrapib in patients at high risk for coronary events. N. Engl. J. Med. 2007, 357, 2109-2122. [CrossRef] [PubMed]

207. Schwartz, G.G.; Olsson, A.G.; Abt, M.; Ballantyne, C.M.; Barter, P.J.; Brumm, J.; Chaitman, B.R.; Holme, I.M.; Kallend, D.; Leiter, L.A.; et al. Effects of dalcetrapib in patients with a recent acute coronary syndrome. N. Engl. J. Med. 2012, 367, 2089-2099. [CrossRef] [PubMed]

208. Lincoff, A.M.; Nicholls, S.J.; Riesmeyer, J.S.; Barter, P.J.; Brewer, H.B.; Fox, K.A.A.; Gibson, C.M.; Granger, C.; Menon, V.; Montalescot, G.; et al. Evacetrapib and cardiovascular outcomes in high-risk vascular disease. N. Engl. J. Med. 2017, 376, 1933-1942. [CrossRef]

209. Bowman, L.; Hopewell, J.C.; Chen, F.; Wallendszus, K.; Stevens, W.; Collins, R.; Wiviott, S.D.; Cannon, C.P.; Braunwald, E.; Sammons, E.; et al. Effects of Anacetrapib in Patients with Atherosclerotic Vascular Disease. N. Engl. J. Med. 2017, 377, 1217-1227. [CrossRef] [PubMed]

210. Grabie, M.; Tai, C.H.; Frishman, W.H. Is Anacetrapib Better Than Its CETP Inhibitor Counterparts? Cardiol. Rev. 2019, 27, 242-248. [CrossRef] [PubMed]

211. Blauw, L.L.; Noordam, R.; Soidinsalo, S.; Blauw, C.A.; Li-Gao, R.; de Mutsert, R.; Berbée, J.F.P.; Wang, Y.; van Heemst, D.; Rosendaal, F.R.; et al. Mendelian randomization reveals unexpected effects of CETP on the lipoprotein profile. Eur. J. Hum. Genet. 2019, 27, 422-431. [CrossRef]

212. Ference, B.A.; Kastelein, J.; Ray, K.K.; Ginsberg, H.N.; Chapman, M.J.; Packard, C.J.; Laufs, U.; Oliver-Williams, C.; Wood, A.M.; Butterworth, A.S.; et al. Association of Triglyceride-Lowering LPL Variants and LDL-C-Lowering LDLR Variants With Risk of Coronary Heart Disease. J. Am. Med. Assoc. 2019, 321, 364-373. [CrossRef] [PubMed] 
213. Ganji, S.H.; Kamanna, V.S.; Kashyap, M.L. Niacin and cholesterol: Role in cardiovascular disease (review). J. Nutr. Biochem. 2003, 14, 298-305. [CrossRef]

214. Bays, H.E.; Shah, A.; Lin, J.; Sisk, C.M.; Dong, Q.; Maccubbin, D. Consistency of extended-release niacin/laropiprant effects on Lp(a), ApoB, non-HDL-C, Apo A1, and ApoB/ApoA1 ratio across patient subgroups. Am. J. Cardiovasc. Drugs 2012, 12, 197-206. [CrossRef]

215. Birjmohun, R.S.; Hutten, B.A.; Kastelein, J.J.; Stroes, E.S. Increasing HDL cholesterol with extended-release nicotinic acid: From promise to practice. Neth. J. Med. 2004, 62, 229-234. [PubMed]

216. Cheng, K.; Wu, T.J.; Wu, K.K.; Sturino, C.; Metters, K.; Gottesdiener, K.; Wright, S.D.; Wang, Z.; O’Neill, G.; Lai, E.; et al. Antagonism of the prostaglandin D2 receptor 1 suppresses nicotinic acid-induced vasodilation in mice and humans. Proc. Natl. Acad. Sci. USA 2006, 103, 6682-6687. [CrossRef]

217. Illingworth, D.R.; Stein, E.A.; Mitchel, Y.B.; Dujovne, C.A.; Frost, P.H.; Knopp, R.H.; Tun, P.; Zupkis, R.V.; Greguski, R.A. Comparative effects of lovastatin and niacin in primary hypercholesterolemia: A prospective trial. Arch. Intern. Med. 1994, 154, 1586-1595. [CrossRef]

218. Knopp, R.H.; Ginsberg, J.; Albers, J.J.; Hoff, C.; Ogilvie, J.T.; Warnick, G.R.; Burrows, E.; Retzlaff, B.; Poole, M. Contrasting effects of unmodified and time-release forms of niacin on lipoproteins in hyperlipidemic subjects: Clues to mechanism of action of niacin. Metabolism 1985, 34, 642-650. [CrossRef]

219. Mills, E.; Prousky, J.; Raskin, G.; Gagnier, J.; Rachlis, B.; Montori, V.M.; Juurlink, D. The safety of over-the-counter niacin: A randomized placebo-controlled trial [ISRCTN18054903]. BMC Clin. Pharmacol. 2003, 3, 4. [CrossRef]

220. Paolini, J.F.; Mitchel, Y.B.; Reyes, R.; Kher, U.; Lai, E.; Watson, D.J.; Norquist, J.M.; Meehan, A.G.; Bays, H.E.; Davidson, M.; et al. Effects of laropiprant on nicotinic acid-induced flushing in patients with dyslipidemia. Am. J. Cardiol. 2008, 101, 625-630. [CrossRef]

221. Sturino, C.F.; O’Neill, G.; Lachance, N.; Boyd, M.; Berthelette, C.; Labelle, M.; Li, L.; Roy, B.; Scheigetz, J.; Tsou, N.; et al. Discovery of a potent and selective prostaglandin D2 receptor antagonist, [(3R)-4-(4-chloro-benzyl)-7-fluoro-5-(methylsulfonyl)-1,2,3,4tetrahydrocy clopenta[b]indol-3-yl]-acetic acid (MK-0524). J. Med. Chem. 2007, 50, 794-806. [CrossRef]

222. Ballantyne, C.; Gleim, G.; Liu, N.; Sisk, C.M.; Johnson-Levonas, A.O.; Mitchel, Y. Efficacy and safety profile of coadministered ER niacin/laropiprant and simvastatin in dyslipidaemia. J. Clin. Lipidol. 2012, 6, 235-243. [CrossRef]

223. Maccubbin, D.; Bays, H.E.; Olsson, A.G.; Elinoff, V.; Elis, A.; Mitchel, Y.; Sirah, W.; Betteridge, A.; Reyes, R.; Yu, Q.; et al. Lipid-modifying efficacy and tolerability of extended-release niacin/laropiprant in patients with primary hypercholesterolaemia or mixed dyslipidaemia. Int. J. Clin. Pract. 2008, 62, 1959-1970. [CrossRef]

224. Haynes, R.; Valdes-Marquez, E.; Hopewell, J.C.; Chen, F.; Li, J.; Parish, S.; Landray, M.J.; Armitage, J.; Baigent, C.; HPS2THRIVE Collaborative Group, HPS2-THRIVE Writing Committee members; et al. Serious Adverse Effects of Extended-release Niacin/Laropiprant: Results from the Heart Protection Study 2-Treatment of HDL to Reduce the Incidence of Vascular Events (HPS2-THRIVE) Trial. Clin. Ther. 2019, 41, 1767-1777. [CrossRef] [PubMed]

225. Yadav, R.; Liu, Y.; Kwok, S.; Hama, S.; France, M.; Eatough, R.; Pemberton, P.; Schofield, J.; Siahmansur, T.J.; Malik, R.; et al. Effect of Extended-Release Niacin on High-Density Lipoprotein (HDL) Functionality, Lipoprotein Metabolism, and Mediators of Vascular Inflammation in Statin-Treated Patients. J. Am. Heart. Assoc. 2015, 4, e001508. [CrossRef] [PubMed]

226. Tomlinson, B.; Chan, P.; Zhang, Y.; Liu, Z.; Lam, C.W.K. Pharmacokinetics of current and emerging treatments for hypercholesterolemia. Expert Opin. Drug Metab. Toxicol. 2020, 16, 371-385. [CrossRef] [PubMed]

227. Sabatine, M.S.; Giugliano, R.P.; Keech, A.C.; Honarpour, N.; Wiviott, S.D.; Murphy, S.A.; Kuder, J.F.; Wang, H.; Liu, T.; Wasserman, S.M.; et al. Evolocumab and clinical outcomes in patients with cardiovascular disease. N. Engl. J. Med. 2017, 376, 1713-1722. [CrossRef]

228. Schwartz, G.G.; Steg, P.G.; Szarek, M.; Bhatt, D.L.; Bittner, V.A.; Diaz, R.; Edelberg, J.M.; Goodman, S.G.; Hanotin, C.; Harrington, R.A.; et al. Alirocumab and cardiovascular outcomes after acute coronary syndrome. N. Engl. J. Med. 2018, 379, 2097-2107. [CrossRef]

229. Colhoun, H.M.; Leiter, L.A.; Müller-Wieland, D.; Cariou, B.; Ray, K.K.; Tinahones, F.J.; Domenger, C.; Letierce, A.; Israel, M.; Samuel, R.; et al. Effect of alirocumab on individuals with type 2 diabetes, high triglycerides, and low high-density lipoprotein cholesterol. Cardiovasc. Diabetol. 2020, 19, 14. [CrossRef]

230. Ying, Q.; Chan, D.C.; Watts, G.F. New Insights into the Regulation of Lipoprotein Metabolism by PCSK9: Lessons From Stable Isotope Tracer Studies in Human Subjects. Front. Physiol. 2021, 12, 603910. [CrossRef]

231. Feng, X.; Berklein, F.; Rane, P.B.; Habib, M.; Lin, P.J. Patient Characteristics and Treatment Patterns among Medicare Beneficiaries Initiating PCSK9 Inhibitor Therapy. Cardiovasc. Drugs Ther. 2021, 35, 965-973. [CrossRef]

232. Tokgozoglu, L.; Kayikcioglu, M. Familial Hypercholesterolemia: Global Burden and Approaches. Curr. Cardiol. Rep. 2021, $23,151$. [CrossRef] [PubMed]

233. Li, N.; Li, Q.; Tian, X.Q.; Qian, H.Y.; Yang, Y.J. Mipomersen is a promising therapy in the management of hypercholesterolemia: A meta-analysis of randomized controlled trials. Am. J. Cardiovasc. Drugs 2014, 14, 367-376. [CrossRef]

234. Mullick, A.E.; Fu, W.; Graham, M.J.; Lee, R.G.; Witchell, D.; Bell, T.A.; Whipple, C.P.; Crooke, R.M. Antisense oligonucleotide reduction of apoB-ameliorated atherosclerosis in LDL receptor-deficient mice. J. Lipid Res. 2011, 52, 885-896. [CrossRef] [PubMed]

235. Yu, Q.; Zhang, Y.; Xu, C.B. Apolipoprotein B, the villain in the drama? Eur. J. Pharmacol. 2015, 748, 166-169. [CrossRef] [PubMed] 
236. Fogacci, F.; Ferri, N.; Toth, P.P.; Ruscica, M.; Corsini, A.; Cicero, A. Efficacy and Safety of Mipomersen: A Systematic Review and Meta-Analysis of Randomized Clinical Trials. Drugs 2019, 79, 751-766. [CrossRef] [PubMed]

237. Available online: https:/ / www.drugs.com/history/kynamro.html (accessed on 4 August 2021).

238. Sirwi, A.; Hussain, M.M. Lipid transfer proteins in the assembly of apoB-containing lipoproteins. J. Lipid Res. 2018, 59, 1094-1102. [CrossRef]

239. Sahebkar, A.; Watts, G.F. New therapies targeting apoB metabolism for high-risk patients with inherited dyslipidaemias: What can the clinician expect? Cardiovasc. Drugs Ther. 2013, 27, 559-567. [CrossRef] [PubMed]

240. Gordon, D.A. Recent advances in elucidating the role of the microsomal triglyceride transfer protein in apolipoprotein B lipoprotein assembly. Curr. Opin. Lipidol. 1997, 8, 131-137. [CrossRef]

241. Alonso, R.; Cuevas, A.; Mata, P. Lomitapide: A review of its clinical use, efficacy, and tolerability. Core Evid. 2019, 14, 19-30. [CrossRef]

242. Kolovou, G.; Diakoumakou, O.; Kolovou, V.; Fountas, E.; Stratakis, S.; Zacharis, E.; Liberopoulos, E.N.; Matsouka, F.; Tsoutsinos, A.; Mastorakou, I.; et al. Microsomal triglyceride transfer protein inhibitor (lomitapide) efficacy in the treatment of patients with homozygous familial hypercholesterolaemia. Eur. J. Prev. Cardiol. 2019, 27, 157-165. [CrossRef]

243. Spinler, S. The pharmacology and therapeutic use of dabigatran etexilate. J. Clin. Pharmacol. 2013, 53, 1-13.

244. Cate, H.T. Dabigatran and apolipoprotein B. Heart 2016, 102, 5-6. [CrossRef]

245. Joseph, P.; Pare, G.; Wallentin, L.; Connolly, S.; Yusuf, S.; Wang, J.; Ezekowitz, M.; Eikelboom, J.; Siegbahn, A.; Reilly, P.; et al. Dabigatran etexilate and reduction in serum apolipoprotein B. Heart 2016, 102, 57-62. [CrossRef]

246. Zhao, X.; Ma, X.; Luo, X.; Shi, Z.; Deng, Z.; Jin, Y.; Xiao, Z.; Tan, L.; Liu, P.; Jiang, S.; et al. Efficacy and safety of bempedoic acid alone or combining with other lipid-lowering therapies in hypercholesterolemic patients: A meta-analysis of randomized controlled trials. BMC Pharmacol. Toxicol. 2020, 21, 86. [CrossRef]

247. Ray, K.K.; Bays, H.E.; Catapano, A.L.; Lalwani, N.D.; Bloedon, L.T.; Sterling, L.R.; Robinson, P.L.; Ballantyne, C.M.; CLEAR Harmony Trial. Safety and Efficacy of Bempedoic Acid to Reduce LDL Cholesterol. N. Engl. J. Med. 2019, 380, 1022-1032. [CrossRef]

248. Ruscica, M.; Zimetti, F.; Adorni, M.P.; Sirtori, C.R.; Lupo, M.G.; Ferri, N. Pharmacological aspects of ANGPTL3 and ANGPTL4 inhibitors: New therapeutic approaches for the treatment of atherogenic dyslipidemia. Pharmacol. Res. 2020, 153, 104653. [CrossRef]

249. Pu, X.; Sale, M.; Yang, F.; Zhang, Y.; Davis, J.D.; Al-Huniti, N. Population pharmacokinetics and exposure-response modeling for evinacumab in homozygous familial hypercholesterolemia. CPT Pharmacomet. Syst. Pharmacol. 2021, in press. [CrossRef] [PubMed]

250. Jin, M.; Meng, F.; Yang, W.; Liang, L.; Wang, H.; Fu, Z. Efficacy and Safety of Evinacumab for the Treatment of Hypercholesterolemia: A Meta-Analysis. J. Cardiovasc. Pharmacol. 2021, 78, 394-402. [CrossRef] [PubMed]

251. Warden, B.A.; Duell, P.B. Evinacumab for treatment of familial hypercholesterolemia. Expert Rev. Cardiovasc. Ther. 2021, 19, 739-751. [CrossRef]

252. Rosenson, R.S.; Underberg, J.A. Systematic Review: Evaluating the Effect of Lipid-Lowering Therapy on Lipoprotein and Lipid Values. Cardiovasc. Drugs Ther. 2013, 27, 465-479. [CrossRef] [PubMed]

253. Elam, M.; Lovato, L.C.; Ginsberg, H. Role of fibrates in cardiovascular disease prevention, the ACCORD-Lipid perspective. Curr Opin. Lipidol. 2011, 22, 55-61. [CrossRef]

254. Bays, H.E.; McKenney, J.M.; Dujovne, C.A.; Schrott, H.G.; Zema, M.J.; Nyberg, J.; MacDougall, D.E. Effectiveness and tolerability of a new lipid-altering agent, gemcabene, in patients with low levels of high-density lipoprotein cholesterol. Am. J. Cardiol. 2003, 92, 538-543. [CrossRef]

255. Warden, B.A.; Duell, P.B. Inclisiran: A Novel Agent for Lowering Apolipoprotein B-containing Lipoproteins. J. Cardiovasc. Pharmacol. 2021, 78, e157-e174. [CrossRef]

256. Soška, V.; Kyselák, O. Some causes of poor adherence to long-term statin therapy and their solution. Vnitřní Lékařství 2018, 64, 923-927. [CrossRef]

257. De Vera, M.A.; Bhole, V.; Burns, L.C.; Lacaille, D. Impact of statin adherence on cardiovascular disease and mortality outcomes: A systematic review. Br. J. Clin. Pharmacol. 2014, 78, 684-698. [CrossRef] [PubMed]

258. Kobiyama, K.; Saigusa, R.; Ley, K. Vaccination against atherosclerosis. Curr. Opin. Immunol. 2019, 59, 15-24. [CrossRef]

259. Amirfakhryan, H. Vaccination against atherosclerosis: An overview. Hell. J. Cardiol. 2020, 61, 78-91. [CrossRef] [PubMed]

260. Lu, K.; Su, B.; Meng, X. Recent Advances in the Development of Vaccines for Diabetes, Hypertension, and Atherosclerosis. J. Diabetes Res. 2018, 24, 1638462. [CrossRef] [PubMed]

261. Gisterå, A.; Klement, M.L.; Polyzos, K.A.; Mailer, R.; Duhlin, A.; Karlsson, M.; Ketelhuth, D.; Hansson, G.K. Low-Density Lipoprotein-Reactive T Cells Regulate Plasma Cholesterol Levels and Development of Atherosclerosis in Humanized Hypercholesterolemic Mice. Circulation 2018, 138, 2513-2526. [CrossRef] [PubMed]

262. Klingenberg, R.; Lebens, M.; Hermansson, A.; Fredrikson, G.N.; Strodthoff, D.; Rudling, M.; Ketelhuth, D.F.; Gerdes, N.; Holmgren, J.; Nilsson, J.; et al. Intranasal immunization with an apolipoprotein B-100 fusion protein induces antigen-specific regulatory T cells and reduces atherosclerosis. Arterioscler. Thromb. Vasc. Biol. 2010, 30, 946-952. [CrossRef]

263. Chyu, K.Y.; Shah, P.K. In Pursuit of an Atherosclerosis Vaccine. Circ. Res. 2018, 123, 1121-1123. [CrossRef] 
264. Nghiem, N.; Knight, J.; Mizdrak, A.; Blakely, T.; Wilson, N. Preventive Pharmacotherapy for Cardiovascular Disease: A Modelling Study Considering Health Gain, Costs, and Cost-Effectiveness when Stratifying by Absolute Risk. Sci. Rep. 2019, 9, 19562. [CrossRef]

265. Sidney, S.; Sorel, M.E.; Quesenberry, C.P.; Jaffe, M.G.; Solomon, M.D.; Nguyen-Huynh, M.N.; Go, A.S.; Rana, J.S. Comparative Trends in Heart Disease, Stroke, and All-Cause Mortality in the United States and a Large Integrated Healthcare Delivery System. Am. J. Med. 2018, 131, 829-836. [CrossRef]

266. Sniderman, A.D.; Thanassoulis, G.; Williams, K.; Pencina, M. Risk of premature cardiovascular disease vs the number of premature cardiovascular events. JAMA Cardiol. 2016, 1, 492-494. [CrossRef] [PubMed]

267. Sidney, S.; Quesenberry, C.P., Jr.; Jaffe, M.G.; Sorel, M.; Nguyen-Huynh, M.N.; Kushi, L.H.; Go, A.S.; Rana, J.S. Recent Trends in Cardiovascular Mortality in the United States and Public Health Goals. JAMA Cardiol. 2016, 1, 594-599. [CrossRef] [PubMed]

268. Dunbar, S.B.; Khavjou, O.A.; Bakas, T.; Hunt, G.; Kirch, R.A.; Leib, A.R.; Morrison, R.S.; Poehler, D.C.; Roger, V.L.; Whitsel, L.P.; et al. Projected Costs of Informal Caregiving for Cardiovascular Disease: 2015 to 2035: A Policy Statement from the American Heart Association. Circulation 2018, 137, e558-e577. [CrossRef] [PubMed]

269. Robinson, J.G.; Huijgen, R.; Ray, K.; Persons, J.; Kastelein, J.J.; Pencina, M.J. Determining When to Add Nonstatin Therapy: A Quantitative Approach. J. Am. Coll. Cardiol. 2016, 68, 2412-2421. [CrossRef] [PubMed]

270. Rosei, E.A.; Salvetti, M. Management of Hypercholesterolemia, Appropriateness of Therapeutic Approaches and New Drugs in Patients with High Cardiovascular Risk. High Blood Press. Cardiovasc. Prev. 2016, 23, 217-230. [CrossRef] [PubMed]

271. Langlois, M.R.; Nordestgaard, B.G.; Langsted, A.; Chapman, M.J.; Aakre, K.M.; Baum, H.; Borén, J.; Bruckert, E.; Catapano, A.; Cobbaert, C.; et al. European Atherosclerosis Society (EAS) and the European Federation of Clinical Chemistry and Laboratory Medicine (EFLM) Joint Consensus Initiative. Quantifying atherogenic lipoproteins for lipid-lowering strategies: Consensus-based recommendations from EAS and EFLM. Clin. Chem. Lab. Med. 2020, 58, 496-517. [PubMed]

272. Solati, Z.; Ravandi, A. Lipidomics of Bioactive Lipids in Acute Coronary Syndromes. Int. J. Mol. Sci. 2019, 20, 1051. [CrossRef]

273. Cobbaert, C.M.; Althaus, H.; Begcevic Brkovic, I.; Ceglarek, U.; Coassin, S.; Delatour, V.; Deprez, L.; Dikaios, I.; Dittrich, J.; Hoofnagle, A.N.; et al. Towards an SI-Traceable Reference Measurement System for Seven Serum Apolipoproteins Using Bottom-Up Quantitative Proteomics: Conceptual Approach Enabled by Cross-Disciplinary/Cross-Sector Collaboration. Clin. Chem. 2021, 67, 478-489. [CrossRef]

274. Bodde, M.C.; Hermans, M.; Jukema, J.W.; Schalij, M.J.; Lijfering, W.M.; Rosendaal, F.R.; Romijn, F.; Ruhaak, L.R.; van der Laarse, A.; Cobbaert, C.M. Apolipoproteins A1, B, and apoB/apoA1 ratio are associated with first ST-segment elevation myocardial infarction but not with recurrent events during long-term follow-up. Clin. Res. Cardiol. 2019, 108, 520-538. [CrossRef] [PubMed]

275. Contois, J.H.; Delatour, V. Apolipoprotein B measurement: Need for standardization. J. Clin. Lipidol. 2018, 12, 264-265. [CrossRef]

276. Delatour, V.; Clouet-Foraison, N.; Gaie-Levrel, F.; Marcovina, S.M.; Hoofnagle, A.N.; Kuklenyik, Z.; Caulfield, M.P.; Otvos, J.D.; Krauss, R.M.; Kulkarni, K.R.; et al. Comparability of Lipoprotein Particle Number Concentrations Across ES-DMA, NMR, LCMS/MS, Immunonephelometry, and VAP: In Search of a Candidate Reference Measurement Procedure for apoB and non-HDL-P Standardization. Clin. Chem. 2018, 64, 1485-1495. [CrossRef] [PubMed]

277. Chang, T.Y.; Chen, J.D. Low-density lipoprotein cholesterol/apolipoprotein B ratio is superior to apolipoprotein B alone in the diagnosis of coronary artery calcification. Coron. Artery Dis. 2021, 32, 561-566. [CrossRef] [PubMed]

278. Drexel, H.; Larcher, B.; Mader, A.; Vonbank, A.; Heinzle, C.F.; Moser, B.; Zanolin-Purin, D.; Saely, C.H. The LDL-C/ApoB ratio predicts major cardiovascular events in patients with established atherosclerotic cardiovascular disease. Atherosclerosis 2021, 329, 44-49. [CrossRef] 